This is the version of the article accepted for publication in Journal of Transatlantic Studies published by Taylor \& Francis: https://doi.org/10.1080/14794012.2015.1125165

Accepted version downloaded from SOAS Research Online: http://eprints.soas.ac.uk/30240

\title{
The US Commitments to NATO in the Post-Cold War Period A Case Study on Libya
}

\author{
Author: Yanan Song
}

\begin{abstract}
The recent history of the US commitment to NATO has been dominated by economic pressures, squabbles over NATO's military performance in Afghanistan, and the apparent American preference for 'leading from behind' in Libya. The case study on Libya will be especially important in exploring the Obama administration's understanding of the purpose of NATO in the context of current economic pressures, domestic US debates about post-War on Terror interventions, and of increasing American preoccupation with Pacific (rather than European) security. In the case of Libya, the US apparently hesitated to unfold military operations against Libyan military targets. It seems to be the first time that the US followed rather than led its European allies to a campaign. The reason why the US was reluctant to intervene in Libya at the very beginning; why it changed its mind to join the operation later; and why it transferred the Libyan mission to NATO and adopted the strategy of 'leading from behind', reflected on not only the redefinition of 'American way of war', but also the future of NATO.
\end{abstract}

Key words: US foreign policy; Obama administration; NATO; Libya; Syria 


\section{Introduction}

The geopolitical conditions which led to the creation of NATO in 1949 rapidly disappeared following the fall of the Berlin Wall in 1989. The new conditions led to an American rethinking of the commitment to NATO, just at it led to a refocusing of priorities within European members of the alliance. In May 1990, NATO's Military Committee announced that it no longer considered the Warsaw Pact a threat to the alliance. President George H.W. Bush then called for spending cuts which would eventually result in significant reductions in funding and force levels for NATO's conventional and nuclear forces. The possibility of the termination of institutionalised US support for European security was seriously raised in this period, as was the possibility of NATO ceasing to exist.

In the immediate aftermath of the Cold War, a range of choices for the future directions of US foreign policy presented themselves. Between the extremes of global policeman and isolationist withdrawal, it seemed likely that the favoured policy would be one that 2 ecognized the dynamics of global political and economic interdependence and integration. Following major debates about the appropriate direction for post-Cold War American internationalism, the Clinton Administration not only committed itself to the continuation of NATO, but also began to sponsor a major programme of NATO renewal and enlargement. After progressive transformation, NATO expanded rather than disbanded. It went on to participate in 'out of area' action in Bosnia, Kosovo, Afghanistan and Libya. It developed a set of more or less concerted doctrine regarding 'new threats'. All these commitments were accompanied by major debates about the purpose and capabilities of NATO. Relevant debates included continuing tensions between Washington and European capitals over defence spending levels; accusations that the US was using NATO as an instrument of extra-United Nations (UN) unilateral power; the preference of Washington immediately after 9/11 for working through ad hoc rather than institutionalised alliance structures; and the developing relationship between NATO and Russia (particularly in the context of possible Georgian and Ukrainian membership of the organisation). However, NATO continued to exist and Washington remained formally committed to the defence of Europe. The recent history of the US commitment has been dominated by economic pressures, squabbles over NATO's military performance in Afghanistan, and the apparent American preference for 'leading from behind' in Libya.

This paper seeks to explain the continuing US commitments to NATO in the postCold War era by researching in some depth the operation in Libya. The case study on Libya is especially important in exploring the Obama Administration's understanding of the purpose of NATO in the context of current economic pressures, domestic US debates about post-War on Terror interventions, and of increasing American preoccupation with Pacific (rather than European) security. The first section of this 
paper introduces the background to the US response to the Libya crisis; the second section analyses why the US hesitate to intervene in Libya at the very beginning; the third section addresses why the US eventually decided to participate in the Libyan mission, but in a way of 'leading from behind'; the final section argues that the socalled 'Libyan model' reflects on not only the redefinition of the 'American way of war', but also the future of NATO. In addition to secondary resources, this paper also draws on interviews with both government officials and academic experts, which have been conducted in Washington D.C. in 2012.

\section{Background to the US response to the Libyan crisis}

Early in 2011, overwhelming anti-government protests swept North Africa: Tunisian President Zine al-Abidine Ben Ali who had been in power for 23 years was forced to flee the country immediately; Egyptian President Muhammed Hosni Mubarak who had maintained his 30-plus year hold on authority had no choice but to step down from office in just 18 days. These astonishing political changes in neighbouring Tunisia and Egypt encouraged similar protests in Algeria, Iraq, Bahrain, Yemen, and Libya.

In response, Libyan security forces opened fire with heavy weaponry on protestors. Fighter jets and helicopter gunships attacked people who had no means to defend themselves. ${ }^{1}$ Sayf al Islam Al Gaddafi, the eldest of Gaddafi's sons, highlighted 'We will eradicate them all' and warned the public that the conflict might escalate into a civil war during his televised speech on February $20{ }^{2}$ Hence, the UN Secretary General Ban Ki-moon said Gaddafi had lost his legitimacy when he declared war on his people, urging Gaddafi that 'the human rights and freedom of assembly and freedom of speech must be fully protected' and that the authorities must immediately halt violence against civilians. ${ }^{3}$ At the end of February, Hillary Clinton travelled to the UN Human Rights Council in Geneva to remind the international community that it had a responsibility to protect universal rights and to hold violators accountable. She said that Gaddafi had 'lost the legitimacy to govern' and 'the people of Libya have made themselves clear: It is time for Gaddafi to go - now, without further violence or delay'. ${ }^{4}$ However, Gaddafi ignored the condemnation and insisted on further repression against demonstrators, which caused a tremendous increase in the death toll. ${ }^{5}$ According to the UN report, protestors killed by Gaddafi's family-led security forces amounted to 1000 in the first 10 days, and civilians that died during the conflict reached 3000 in just half a month. ${ }^{6}$ But Libyan state TV denied there had

\footnotetext{
1 'Libya: Benghazi Clashes Deadly_—Witnesses', BBC News, 18 February 2011.

2 'Gaddafi Son: "We Will Eradicate Them All”', The Guardian, 21 February 2011. 'Libya on Brink As Protests Hit Tripoli', The Guardian, 21 February 2011.

3 'Libyan Leader Muammar Gaddafi Appears on State TV', BBC News, 22 February 2011. 'Security Council Authorises “All Necessary Measures" to Protect Civilians in Libya', UN News Centre, 17 March 2011.

${ }^{4}$ Hillary Clinton's memoir: Clinton (2014) Hard Choices, London: Simon and Schuster, 365.

5 'Death Toll in Libya Protest "Hits 120"', Sky News, 19 February 2011.

${ }^{6}$ On 25 February 2011, according to resolution S-15/1 entitled 'Situation of Human Rights in the Libyan Arab
} 
been any massacres, dismissing the report as 'baseless lies' by foreign media. Gaddafi even called foreign news channels 'dogs' when he appeared on state television on 22 February. ${ }^{7}$ Regarding Gaddafi's comment as an insult, Libya's diplomats at the UN in New York including Deputy Permanent Representative Ibrahim Dabbashi and Libya's most senior diplomat Ali Aujali, called for international intervention to stop Gaddafi's violent action against street demonstration in their homeland. ${ }^{8}$

However, America hesitated to take any military action. 'America, it is time to focus on nation-building here at home. ${ }^{9}$ President Obama restated his doctrine of opposing more military entanglements and scaling down the US commitments overseas when announcing the withdrawal of American troops from Afghanistan in June 2011. There seemed to be a strong sense among an overwhelming majority of policymakers and the public that America should no longer declare new conflict involvements, given the overstretched position due to the wars in Afghanistan and Iraq, and the pressures for austerity at home. In such circumstances, Robert Gates, then-Secretary of Defence, became one of the pioneers to oppose US involvement in Libya. In March 2011, he made a statement as follows: 'My view would be, if there is going to be that kind of assistance (providing arms) to the opposition, there are plenty of sources for it other than the United States.' He further added that NATO would act only 'if there is demonstrable need, a sound legal basis and strong regional support' for military action. ${ }^{10}$ Far worse was Gates' answer when asked if there would be US 'boots on the ground'. According to the New York Times, Gates swiftly replied 'Not as long as I am in this job'. ${ }^{11}$ As a result, prior to the adoption of the UN Security Resolution 1973 which authorised 'all necessary means' to protect civilians, America hesitated to make any stance, in addition to delivering several vague speeches: the highest-level statement at that moment by the US government on the accelerating strife in Libya was made by Secretary of State Hillary Clinton who, though condemning the violence in Libya and calling for a halt to the 'unacceptable bloodshed' in response to civil unrest, only aimed to 'convey this message to the Libyan government' rather than claiming US support of the Libyan people. ${ }^{12}$

\footnotetext{
Jamahiriya', the UN's Human Rights Council established the International Commission of Inquiry on Libya and gave it the mandate 'to investigate all alleged violations of international human rights law in Libya, to establish the facts and circumstances of such violations and of the crimes perpetrated and, where possible, to identify those responsible, to make recommendations, in particular, on accountability measures, all with a view to ensuring that those individuals responsible are held accountable'. See A/HRC/S-15/1, 'Report of the Human Rights Council on Its Fifteenth Special Session', 25 February 2011; and A/HRC/19/68, 'Report of the International Commission of Inquiry on Libya', 02 March 2012.

7 'Libyan Leader Muammar Gaddafi Appears on State TV', BBC News, 22 February 2011.

8 'Libyan Leader Muammar Gaddafi Appears on State TV'.

9 'Time to Focus on Nation Building Here at Home', ABC News, 22 June 2011.

${ }^{10}$ Karen Parrish (2011) 'Gates: NATO's Libya Plans To Include Military Options', US Fed News, 10 March. Gates' idea was also shared by the Alliance's Secretary General Anders Fogh Rasmussen, who told reporters that NATO was considering a 'range of options', including humanitarian help, but that any move would be governed by three principles: that there was 'demonstrable need', a 'clear legal basis' and 'firm regional support'. See Alan Cowell and Steven Erlanger (2011) 'France Becomes First Country to Recognise Libyan Rebels', The New York Times, 10 March.

${ }^{11}$ Elisabeth Bumiller and Thom Shanker (2011) '2 Cabinet Officials Say US Isn't Likely to Arm Libyans', The New York Times, 31 March. Elliott Abrams (2011) 'Mr. Gates Oversteps', The Council on Foreign Relations, 31 March. 'Gates: No US Ground Troops in Libya on His Watch', USA Today, 31 March.

12 "Clinton to Libya: End "Unacceptable Bloodshed"', CNN, 22 February 2011. The UN Security Council
} 


\section{Why did the US hesitate to intervene in Libya at the very beginning?}

\section{Low public enthusiasm for a third Middle East war}

There were many arguments that tried to disconnect what was happening in Libya from US strategic interests. Firstly, public support was very low in the context of financial crisis and in particular the wars in Iraq and Afghanistan. Ambassador Kathleen Stephens believed that the American people understood that to retain a leadership role in the world, fundamentally the US needed to be strong and competitive in economy and infrastructure, therefore performing the Libyan mission would not be an acceptable choice among the mass. ${ }^{13}$ In addition, considering both wars in Iraq and Afghanistan had become increasingly unpopular with most Americans, Robert Litwak argued that fatigue of the two wars and uncertainty about what the outcome would be in Libya were the main factors that decreased the Administration's enthusiasm for getting involved in another Middle East war. ${ }^{14}$ Steven Heydemann also agreed that public tolerance for military engagement was quite low after 10 years war in Iraq and Afghanistan, which produced a national fatigue for intervention. ${ }^{15}$

In reality, not only current public opinion towards war, but also how the Administration viewed a further military engagement, have been greatly influenced by the legacy of previous wars. Barack Obama is the president who campaigned on ending the wars in Iraq, on reaching out of the Muslim World, and on building a better relationship between the US and the Arab World, thus starting another war against an Arab Muslim country was seen as highly undesirable for the Administration. ${ }^{16}$ Both Matthew Kroenig and Nora Bensahel emphasised that it would be politically dangerous for President Obama to announce the intervention, not only in terms of how it would be perceived but also how it would be in reality of getting involved in a third Middle East war. ${ }^{17}$ Even though France and Britain took the lead to declare war against Gaddafi, the Obama Administration remained silent because its policy was extended at hand.

\section{An American project or a European project?}

Secondly, it was widely accepted that there were no direct, first-order US interests at stake in Libya, hence the US response to a state that imposed no threat to American

\footnotetext{
Resolution 1973, 17 March 2011.

${ }^{13}$ Interview with Kathleen Stephens, US Ambassador to South Korea, 18 July 2012.

${ }^{14}$ Interview with Robert Litwak, Vice President for Scholars and Director of international Security Studies at the Woodrow Wilson Center, 10 July 2012.

${ }^{15}$ Interview with Steven Heydemann.

${ }^{16}$ President Obama (2008) 'Obama's Speech on Iraq', Council on Foreign Relations, 19 March. President Obama (2008) 'Obama's Remarks on Iraq and Afghanistan', The New York Times, 15 July. 'Barack Obama and What He Said on the Iraq War', The Telegraph, 14 December 2011. President Obama (2010) 'Address to the Nation on the End of Combat Operations in Iraq', 31 August.

${ }^{17}$ Interview with Nora Bensahel; interview with Matthew Kroenig, Stanton nuclear Security Fellow at the Council on Foreign Relations, 17 July 2012.
} 
people would not be necessary. Steven Heydemann supported this idea by saying that it was difficult to argue that Libya rose above the threshold that made it a vital strategic interest for the US. ${ }^{18}$ Thus 'Nowhere in the administration's public statements was there any assessment of US interests in Libya that would justify American military intervention'. ${ }^{19}$ In terms of hard-core national interests, as Christopher Chivvis mentioned, the US did not see Libya as attractive in the field of energy or gas, but the European allies were getting gas and oil from Libya through enormous contracts. ${ }^{20}$ How the Libyan crisis had affected European countries' economic interests was evidenced by the increase of oil prices to their highest levels since the global financial crisis of 2008 due to Gaddafi's plan to end Libya's National Oil Corporation's (NOP) contracts with Western oil groups including oil giant BP. ${ }^{21}$ Furthermore, European security was more directly challenged because geographically Europe was closer to Libya, therefore potential refugees would flow across Mediterranean and destabilise the European governments and economies. With respect to this, Karim Mezran compared the US attitudes toward Iraq and Libya, concluding that the reason why the US was active in Afghanistan and passive in Libya was because Afghanistan was an American project while Libya was a European project. ${ }^{22}$ But, since the Libyan mission was related to European interests, how could the US avoid getting involved, given the intimate transatlantic relationship?

Theoretically whether a mission is an American project or a European project depends on who is responding to the attack, but this definition is apparently inappropriate taking into account the narrow and limited basis. For example, Afghanistan was an American project in the sense that the US was responding to the attack, but it was also very international from the beginning in terms of the understanding of why Afghanistan mattered. The US got expressions of support from every country around the world that understood what happened on 11 September 2001 was an attack on the US and thereby a military response would be seen as self-defence. There were tremendous international involvements starting in January 2002, in view of a shared belief that reconstruction was necessary to prevent the disaster from happening again. It was true that the US was leading the military operation, yet the US also received remarkable support from other countries. Even Russia and China had openly expressed their support, regarding US military activity in Afghanistan as self-defence. In that sense, it would be unfair to define Afghanistan solely as an American project, and similarly, Libya should not be considered as a European project though no direct US interests were actually at stake.

\footnotetext{
${ }^{18}$ Interview with Steven Heydemann.

${ }^{19}$ Martin Indyk, Kenneth Lieberthal and Michael O'Hanlon. (2012) Bending History: Barack Obama's Foreign Policy, Washington: Brookings Institution Press, p. 161.

${ }^{20}$ Interview with Christopher Chivvis, Senior Political Scientist at RAND, 16 July 2012.

${ }^{21}$ Garry White (2011) 'BP's Contracts in Libya "Still Valid” Despite Turmoil', The Telegraph, 17 March. 'Libyan Leader Muammar Gaddafi Appears on State TV', BBC News, 22 February 2011. Although Gaddafi did not really replace Western oil groups with companies from Russia, India and China, his comments and the unrest in Libya did suspend BP's and Royal Dutch Shell's exploration programmes.

${ }^{22}$ Interview with Karim Mezran, Senior Fellow at the Atlantic Council, 09 July 2012.
} 


\section{Pragmatic reasons}

Whenever the US decides to intervene in a regional crisis, it knows that it has to do a large amount of the work, implementing most part of the campaign and investing ample resources, technologies, intelligences, surveillances, air-refueling, etc. Usually the US is not reluctant to take actions as long as it suspects that (potential) threats exist or US interests are at stake there. This assumption enables the US to play a dominant role in crisis management around the world, which also incidentally brings more responsibilities to the US at the same time. The pre-war estimation demonstrated that Libya would not be an exception in terms of resources spending. If the US, rather than France and Britain, took the lead in Libya, it would have provided the majority of forces as it did in the past to make it possible. But in the situation where the US had its forces committed in many other parts of the world, the recognition about what Libya would take for the US was uncertain. Dominique de Villepin, the French minister of Foreign Affairs, made a judgment prior to the invasion of Iraq, warning that intervention was not only about winning the campaign, but also about continuing with post-war peace-building tasks.

The option of war might seem a priori to be the swiftest. But let us not forget that having won the war, one has to build peace. Let us not delude ourselves. This will be long and difficult because it will be necessary to preserve Iraq's unity and restore stability in a lasting way in a country and region harshly affected by the intrusion of force. ${ }^{23}$

Nonetheless, Washington dismissed such prescient warnings. It soon saw Iraq becoming a miserable story. The lesson from Iraq, particularly with regard to the underestimated costs and time spent on that mission, highly constrained the Americans' tolerance for helping transform one more country like Iraq. Indeed, how could a country, with anticipation that the costs of war would be much higher than the benefits regardless of the necessity to join that war, agree to take actions concretely?

To sum up, apparently, the reason why America was reluctant to intervene in Libya at first lay in domestic pressures. The legacy of the US 'War on Terror' scared both the US policy-makers and the public, who could not bear the US sinking into another 'quagmire' as in the cases of Afghanistan and Iraq. Inside the Administration, the debate mainly centred on the question of humanitarian intervention - whether it was worth 'saving strangers' regardless of cost - one that continued to vex the governments of the US and other democracies. ${ }^{24}$ According to Susan Rice, the Iraq war had set back the cause of humanitarian intervention by discrediting American military missions abroad and making it more difficult to rally consensus to stop a massacre. ${ }^{25}$ But when economic sanctions and diplomatic means were proved failures in stopping Gaddafi and when those innocent civilians were pleading with the

\footnotetext{
${ }^{23}$ Dominique de Villepin (2003) 'Statement by Dominique de Villepin to the UNSC', Foreign Policy, 14 February 2003.

${ }^{24}$ Nicholas Wheeler (2002) Saving Strangers: Humanitarian Intervention in International Society, Oxford: Oxford University Press.

${ }^{25}$ Massimo Calabresi (2011) ‘Susan Rice: A Voice for Intervention’, Time, 24 March.
} 
international community to save them, should the US continue to brush off the enquiry with meaningless verbal condemnation? ${ }^{26}$ It was understandable that Washington was under considerable military, economic and political pressure due to its overstretched position around the world, but was that a persuasive argument on US inability to conduct necessary military intervention, given Gaddafi's brutality and intransigence, the Arab leaders' hostility toward Gaddafi, and the determination by Britain and France that military intervention in Libya was in their interests?

\section{Why did the US eventually decide to participate in the Libyan mission?}

\section{The realistic dimension: traditional national interests were present}

From a pure realist perspective, the roots of intervening in Libya were inadequate in the sense that there were no direct, first-order US interests at stake. However, though acknowledging that America's security was not threatened, President Obama emphasised that he had a responsibility to act when the US 'interests and values' were at risk. According to him, 'That is what happened in Libya over the course of these last six weeks. ${ }^{27}$ Charles Kupchan mentioned that traditional national interests were not completely absent in Libya. He underlined two categories of national interests that were involved in Libya. ${ }^{28}$ On one hand, taking actions in Libya was an important step in providing support for the Arab Spring and in sending a signal that crackdowns on democratic protests would not be tolerated. On the other hand, by highlighting external pressures from actors such as the French, the British, and the Arab League, the US did not want to be seen as blocked to act by others because it had, for a long time, been encouraging others to be more proactive and more responsible.

Christopher Chivvis took the same view on where the national security interests were, emphasising the main one was to show support for the revolutions that were taking place across the Arab World. He also agreed that the US was facing pressures from other countries, yet he stressed on the original intention for intervening was to help the allies rather than to passively respond to those pressures. ${ }^{29}$ There was a concern that if the situation went out of control in Libya, anxieties would spread across borders to the east and west of Egypt, thereby lots of refugees would go to Europe, which would become a tremendous threat to the allies. Reducing the allies' security would reduce the US own security in a second way, given that they both belonged to the same alliance that embraced the principle that 'an attack against one member state is considered an attack against all'. When the ABC News' Senior White House Correspondent Jake Tapper asked Secretary of Defence Robert Gates on the 'This

\footnotetext{
${ }^{26}$ According to a Gullup poll conducted in $2012,75 \%$ of the Libyans said that they favoured intervention and supported NATO's military involvement in their nation's conflict. See Jay Loschky (2012) 'Opinion Briefing: Libyans Eye New Relations With the West', Gullup Politics, 13 August.

${ }^{27}$ President Obama (2011) Obama Libya Speech: US ‘Interests and Values’ at Risk, 28 March.

${ }^{28}$ Interview with Charles Kupchan.

${ }^{29}$ Interview with Christopher Chivvis.
} 
Week' show about whether Libya posed an actual or imminent threat to the US, Gates answered 'No...but the engagement of the Arabs, the engagement of the Europeans, the general humanitarian question that was at stake'. ${ }^{30}$ Generally the US perceived at least two traditional national interests at stake in Libya: to encourage those Arab countries that were fighting for democracy and to assist the allies who used to support the US when needed. More importantly, US policy on Libya was consistent with Obama's grand strategy on 'counterpunching' that the Administration 'has been willing to assert its influence and ideals across the globe when challenged by other countries, reassuring allies and signalling resolve to rivals'. ${ }^{31}$

\section{Encourage Arab countries}

In 'Obama's Interventions: Afghanistan, Iraq, Libya', Luca Tardelli was on target arguing that 'Obama's decision to intervene in Libya resulted from the administration's desire to both avert a possible humanitarian disaster in Benghazi as well as to safeguard the revolutionary transitions taking place both in Libya and neighbouring countries' ${ }^{32}$ Stephen Flanagan shared the same view, predicting that if Gaddafi were allowed to undertake actions against Benghazi and others in the west, it would have been a signal to other authoritarian leaders in the Middle East that the West would not bother if they could just kill enough people. ${ }^{33}$ From the US policy perspective, there was a great hope about the Arab awakening in the Arab Spring. In Obama's speech on the Middle East and North Africa on 19 May 2011, the President identified the Arab Spring as a 'historical opportunity' to translate US support for 'political and economic reform in the Middle East and North Africa that can meet the legitimate aspirations of ordinary people throughout the region' into concrete actions. ${ }^{34}$ Hillary Clinton, the Secretary of State, also reaffirmed the American conviction that 'real democratic change... is in the national interest of the US'. ${ }^{35}$ Their analysis proved admirably accurate, in that if Gaddafi were able to depict himself as impregnable, it would have been very damaging to the rest of what was happening in the Arab World. Some of the other authoritarian regimes would decide to use brutal repression as a way to end protests as well. Robert Gates believed that a potential significantly destabilising event taking place in Libya would put the revolutions in both Tunisia and Egypt at risk, given that Libya was a "part of a broader wave of unrest across North Africa and the Middle East that had led to the ousting of longstanding regimes in Tunisia and Egypt'. ${ }^{36}$ These concerns resulted in the formation of a very strong group of advisers, which was led by the Special Assistant to the President Samantha Power, the US Ambassador to the UN Susan Rice and Hillary

\footnotetext{
${ }^{30}$ Joshua Miller (2011) 'Defence Secretary: Libya did not pose threat to US, was not "vital national interest" to intervene', $A B C$ News, 27 March.

${ }^{31}$ Daniel Drezner (2011) 'Does Obama Have a Grand Strategy?: Why We Need Doctrines in Uncertain Times', Foreign Affairs, July/August Issue.

${ }^{32}$ Luca Tardelli (2011) p22.

${ }^{33}$ Interview with Stephen Flanagan.

${ }^{34}$ President Obama (2011) Remarks by the President on the Middle East and North Africa, 19 May.

${ }^{35}$ Luca Tardelli (2011) p21.

${ }^{36}$ Joshua Miller (2011). 'Security Council Authorises “All Necessary Measures” to Protect Civilians in Libya', UN News Centre, 17 March.
} 
Clinton, warning that the US inaction would undermine the process of political change in the Middle East. ${ }^{37}$ Thus, the consensus became clear that only through intervention could the US avoid sending this kind of wrong message that the international community would allow this kind of slaughter to continue recklessly.

\section{Assist European allies}

It was worth questioning whether the US was 'pushed' by the other countries to participate in the Libyan mission? Or was the US 'self-motivated' by the notion that 'your allies' interests become your interests'? In other words, did Washington give priority to the need of helping European allies when making decision on whether to intervene in Libya? James Lindsay insisted that in the case of Libya, the Administration would hardly do anything if it had not been through the French and the British lobbying Washington because there were certainly plenty of other places that were calling for humanitarian interventions. ${ }^{38}$ President Obama and Hillary Clinton found themselves driven by concerns on what the allies wanted, which had ever happened in Kosovo where the allies knew clearly about what should be done there. Similarly in Libya, the French and the British were well aware of the necessity to get involved: 'Despite all negative comments, Libya shows that there is a political and diplomatic dynamic of European construction and an active European voice in world affairs'. ${ }^{39}$ Lindsay's argument was mainly based on the realistic and strategic assumption that Washington had very little at stake in Libya, but he ignored the fact that if Washington understood it was crucial to help its allies in Libya, it would join the operation regardless of whether or when its allies made the request; yet if Washington denied the emergency to provide support to its allies, it would not announce participation even if its allies required. Perhaps a better explanation would be that US decision on Libya was accelerated, not determined, by the French and the British lobbying. The US might have already noticed its allies had immense interests in peril. For example, France and Britain were worried about the potential instability and the increasing violent extremism, and Italy was particularly concerned about the potential refugees. ${ }^{40}$ Without doubt, when two very close US allies, France and Britain, were asking the US to get involved, the possibility of US engagement in Libya would certainly increase. According to Hillary Clinton, 'How could you stand by when France and the UK and other Europeans and the Arab League and your Arab partners were saying you have got to do something?' ${ }^{41}$ Thus, the internal belief-

\footnotetext{
${ }^{37}$ James Mann (2012) The Obamians: The Struggle Inside the White House to Redefine American Power, New York: Viking. David Gergen (2011) 'What Is Obama's Endgame in Libya?', CNN, 21 March.

${ }^{38}$ Interview with James Lindsay, Senior Vice President, Director of Studies and Maurice R. Greenberg Chair at the Council on Foreign Relations, 10 July 2012.

${ }^{39}$ This is said by Bernard Valero, the spokesman of the French Foreign Ministry. See Steven Erlanger (2011) 'France and Britain Lead Military Push on Libya', The New York Times, 18 March.

${ }^{40}$ Specifically, France played a vanguard role in carrying out intervention in Libya, because it had a very large immigrant population that originated in the Maghreb, and for which the 'Arab Spring' was vitally important and a source of fascination and pride. See Dominique Moisi (2011) 'France Had A Duty to Intervene in Libya', The Guardian, 23 March.

${ }^{41}$ Joshua Miller (2011) 'Defence Secretary: Libya did not pose threat to US, was not "vital national interest" to intervene'.
} 
'though the strategic interest was not direct in Libya, there was a strategic interest in helping US allies'___ultimately facilitated US intervention in Libya. ${ }^{42}$

Moreover, Libya witnessed a critical moment when the Europeans were willing to do something on their own, which had long been expected by the US. France and Britain had mentioned clearly at the very start that they intended to take the lead in enforcing a no-fly zone. Spain, Norway and Denmark quickly expressed their support by saying that they would contribute to the operation. ${ }^{43}$ To have the Europeans shoulder more in terms of defence both in and outside of Europe was exactly what the US had wished to see since the end of the Cold War. With respect to that, Libya became an opportunity for the US to offer assistance in a way of encouraging its allies to make more contributions to future tasks. The good function of an alliance is based on all members' respect for the principle that 'you help me, I help you'. Each member is expecting from an alliance that it will get something in return, not simply 'do somebody's laundry'. There is no exception to the US. In the case of Libya, Washington was of course willing to see European capitals volunteer to assume the responsibility, yet at the same time it was also willing to provide necessary help when required. Last but not least, offering its allies support was also beneficial to consolidating the US position as a leader in the global security architecture. Although Washington repeatedly asked the European capitals to shoulder more responsibility, it did not mean that the US was hoping for a real shift towards a more balanced partnership with Europe, in which the US would give up its dominant role. Therefore, when the allies asked for US assistance in Libya, it simultaneously reaffirmed the perception of how important the US was to the international security system. In this sense, the US was certainly motivated by self-fulfilment rather than persuaded or pushed by its allies to take actions in Libya, though the request from the Europeans also played an essential role.

\section{The humanitarian dimension: another 'Afghanistan' or another 'Rwanda'?}

There is no doubt that the Libyan mission served some US interests, yet the understanding of what US interests were involved in Libya was not wide-spread at the beginning. As a result, a heated debate arose among officials in the Administration over whether to take actions in Libya, entailing how realism versus liberal internationalism could exert influence on US foreign policy. Inside the Administration, senior officials were lined up on both sides. On one hand, Robert Gates, then-US Secretary of Defence, Thomas Donilon, National Security Advisor, and John Brennan, the chief counterterrorism adviser to Obama, strongly opposed to the intervention in Libya. Bearing realists' calculations in mind, they urged caution by arguing that 'Libya was not vital to American national security interests'. ${ }^{44}$ Gates made his views known at the very beginning, saying that the US should stick to offering

\footnotetext{
${ }^{42}$ Interview with Nora Bensahel.

${ }^{43}$ Steven Erlanger (2011).

${ }^{44}$ Helene Cooper (2011) 'Obama Takes Hard Line With Libya After Shift by Clinton', The New York Times, 18 March.
} 
communications, surveillance and other support rather than putting its 'boots on the ground'. He was opposed to attacking Libya and had said as much in several public statements. Donilon was also reportedly wary of the effects of committing to a lengthy military mission in Libya. ${ }^{45}$ As he stressed, the US had already been in wars in Iraq and Afghanistan, not to mention that there were other more urgent national security threats on the rise such as the Iran nuclear programme. Brennan even expressed his concern that the Libyan rebels remained largely unknown to US officials, and could have ties to Al-Qaeda. According to him, groups such as AlQaeda in the Islamic Maghreb were active in Algeria and other countries in the region and had sought to bolster the opposition to Gaddafi, raising fears about the type of government that could replace the four-decade-old dictatorship if it fell. ${ }^{46}$ In general, people in Gates' camp shared concerns about US involvement in Libya, further warning the Administration that the Libyan war might turn out to be another deadlocked 'Afghanistan', which had already become a nightmare of all Americans.

On the other hand, Samantha Power, who was not only the Special Assistant to President Obama but also a writer of a Pulitzer Prize winning book about the genocide in Rwanda a decade ago, formed the other influential camp within the government with Susan Rice, the US Ambassador to the UN, and Hillary Clinton, the Secretary of State, expecting to accelerate US steps to take actions in Libya. As major advocates, they were mainly concerned that the Libyan crisis would deteriorate into another 'Rwanda', where 'the Security Council fails even to consider taking decisive action in the face of genocide, mass murder, and/or ethnic cleansing ${ }^{47}$. Dating back to December 2007 when then-Senator Hillary Clinton was interviewed on 'This Week' show, she had already expressed her regrets about Rwanda and stressed her determination to prevent 'more Rwandas' in the future: 'I think that for me it was one of the most poignant and difficult experiences when...I was able to go to Rwanda and be part of expressing our deep regrets because we did not speak out adequately enough and we certainly did not take action. ${ }^{48}$ In the case of Libya, Hillary Clinton again recalled those instances from recent history when a lack of US intervention had left hundreds of thousands dead, emphasising that the 'Responsibility to Protect' (R2P) was acquired as humanitarian emergency arose. She said that the UN-backed military intervention in Libya would be 'a watershed moment in international decision-making. We learned a lot in the 1990s. We saw what happened in Rwanda. It took a long time in the Balkans, in Kosovo to deal with a tyrant'. ${ }^{49}$

Susan Rice was a staffer at the National Security Council (NSC) when the world failed to stop the genocide in Rwanda. According to the Time magazine, Susan Rice once told Samantha Power, who was then a Harvard scholar, 'I swore to myself that if

\footnotetext{
45 Josh Rogin (2011) 'How Obama Turned on A Dime Toward War', Foreign Policy, 18 March.

${ }^{46}$ Evan Perez (2011) 'Brennan: US Wary of Terrorism in Libya', The Wall Street Journal, 18 March.

${ }^{47}$ Nicholas J. Wheeler (2005) 'A Victory for Common Humanity? The Responsibility to Protect after the 2005

World Summit', Conference on 'The UN at Sixty: Celebration or Wake?', 6-7 October 2005, p 1.

${ }^{48}$ Hillary: No 'Formal' Role for Bill, ABC News, 31 December 2007.

${ }^{49}$ Joshua Miller (2011).
} 
I ever faced such a crisis (as Rwanda) again, I would come down on the side of dramatic action, going down in flames if that was required. ${ }^{50}$ As Gaddafi's troops closed in on the rebel stronghold of Benghazi on 15 March 2011, Obama put the fate of the city's one million residents in the hands of Rice who, as the US Ambassador to the UN, was determined to get a tougher resolution allowing broader intervention. Rice stated that humanitarian intervention was not about going to war for imminent national security needs but to save innocent lives. Hence, she moved on to stress that Gaddafi's violence had already placed the question of when to intervene to save lives squarely on the table. ${ }^{51}$ Samantha Power was also one of the Obamians with deepseated ideas on the issue of Libya. In the light of press reports of Samantha Power, it would be extremely embarrassing to have people again criticise Washington for decades that it had stood by while the Libyan massacre was going on. ${ }^{52}$

Now, the three women were pushing for US intervention to stop a looming humanitarian catastrophe in Libya. Senator John Kerry (D-MA) depicted the debate within the Administration as 'healthy', reemphasising that 'the memory of Rwanda, alongside Iraq, made it clear' that the US needed to act. ${ }^{53}$ As the potential slaughter of the Libyan Benghazi uprising framed around a need for humanitarian intervention, Power's camp began to play a more important role. The broad outline of a reason for US intervention became visible. President Obama was eventually convinced by the humanitarian calculations that the US had the responsibility to prevent Gaddafi from slaughtering innocent civilians, stating that the UN, the Arab League and other countries 'are saying we need to intercede to make sure that a disaster does not happen on our watch as has happened in the past when the international community stood idly by'. ${ }^{54} \mathrm{He}$ further rejected the argument for inaction when defending US military involvement in Libya as a necessary humanitarian intervention on $28 \mathrm{March}$, saying that

To brush aside America's responsibility as a leader and_—more profoundly_ our responsibilities to our fellow human beings under such circumstances would have been a betrayal of who we are...Some nations may be able to turn a blind eye to atrocities in other countries. The United States of America is different. And as President, I refused to wait for the images of slaughter and mass graves before taking action..$^{55}$

Actually before the senior-level meeting was held at the White House on 15 March the consensus around Washington was that military action against Libya was not in the cards. However, after the meeting where 'the President was referring to the broader change going on in the Middle East and the need to rebalance US foreign policy toward a greater focus on democracy and human rights', the White House

\footnotetext{
${ }^{50}$ Michael Crowley (2011) 'Susan Rice, Samantha Power, Rwanda and Libya', Time, 24 March. Massimo Calabresi (2011) 'Susan Rice: A Voice for Intervention', Time, 24 March.

${ }^{51}$ Massimo Calabresi (2011).

52 James Mann (2012).

${ }^{53}$ Helene Cooper (2011).

${ }^{54}$ David Jackson (2011) 'One Reason for Obama's Decision on Libya: Rwanda', The Oval, 24 March.

${ }^{55}$ President Obama (2011) Obama Libya Speech: US ‘Interests and Values’ at Risk, 28 March.
} 
completely altered its stance and successfully pushed for the authorisation for military intervention in Libya. ${ }^{56}$ Steve Clemons, the foreign policy chief at the New America Foundation summarised that 'Gates is clearly not on board with what is going on...Clinton won the bureaucratic battle to use DOD resources to achieve what is essentially the State Department's objective... and Obama let it happen'. ${ }^{57}$ It was true that 'Hillary and Susan Rice were key parts of this story because Hillary got the Arab buy-in and Susan worked the UN to get a 10-to-5 vote, which is no easy thing', but it was also worth noting that the key decision was in fact made by Obama himself. ${ }^{58}$ Matthew Kroenig recalled the story he had been told by a government official that on 15 March, the President listened to the options being presented at the meeting, then he left the room and thought about it and then on his own made the decision that he did not want another Rwanda and was prepared to intervene even though there might not be enough interests at stake. ${ }^{59}$

For the President, the US had to take actions to show the world that this was something the Americans were not acting out of any narrow interests. There was no secret plan to get the Libyan oil or to do something else that would take over Libya. It was truly a response to an international demand. In other words, for the US, 'Libya was a special case__ urgent military intervention was required to stave off a humanitarian disaster'. ${ }^{60}$ As James Mann concludes in 'The Obamians', President Obama's intervention in Libya demonstrated for the first time that he was willing to put the American military to work on behalf of humanitarian goals, in a way that the realists he admired would not. ${ }^{61}$ But if the decision was simply driven by liberal internationalists' considerations, why not Somalia or Congo, where people were also suffering from humanitarian crisis the same as the Libyan? Why did Obama's stance in Libya differ significantly from his strategy regarding the other Arab revolutions? ${ }^{62}$ A lot of people believed these differences undermined the humanitarian claims that the US leaders made about their objectives in intervening in Libya. Moreover, as time wore on and the Syrian death toll mounted, the explanation that the US intervened in Libya mainly because of humanitarian consideration became increasingly implausible. In fact, the reality was not that simple. There was actually a third dimension that often left out of discussion, namely feasibility.

\section{A third dimension: feasibility}

\section{Legitimacy}

\footnotetext{
${ }^{56}$ Josh Rogin (2011).

${ }^{57}$ Ibid.

${ }^{58}$ The statement was made by Brian Katulis, a national security expert with the Centre for American Progress, a liberal group with close ties to the administration. See Helene Cooper (2011).

${ }^{59}$ Interview with Matthew Kroenig.

${ }^{60}$ Martin Indyk, Kenneth Lieberthal, and Michael O’Hanlon (2012) p. 172.

61 James Mann (2012).

${ }^{62}$ In Egypt and Tunisia, Obama chose to rebalance US stance gradually backing away from support for President Hosni Mubarak and Zine el-Abidine Ben Ali and allowing the popular movements to run their course. In Yemen and Bahrain, where the uprising have turned violent, Obama has not even uttered a word in support of armed intervention__ instead pressing those regimes to embrace reform on their own. See Josh Rogin (2011).
} 
Christopher Chivvis thought the reason why the US intervened in Libya rather than Congo or Somalia was because Libya was feasible. The source of its feasibility, as he identified, came from legitimacy. ${ }^{63}$ It was the fact that Gaddafi was the spy of broader international community, including the Arab World, hence there was far-ranging support for this intervention not only in the US and Europe, but also in the region itself. $^{64}$ This was a very important condition that made the intervention possible and legitimate. In addition, China and Russia did not stand in the way, facilitating the adoption of a UN Security Council Resolution that authorised member states to take military actions. ${ }^{65}$ There has always been functional value placed on getting international approval. What would happen in the Gulf War if George H. W. Bush were unable to get the UN Security Council Resolution? The authorisation was important, whereas it did not mean that the US would not occasionally intervene even without a UN Security Council Resolution. The reason why the President went to get the UN authorisation was not because he regarded it as vital to wage a war, instead, he made the calculation that it would enable the US to avoid political problems at home. Similarly in the case of Libya, the US did not take any action until the UN legitimised it, which helped Washington obtain both strategic and moral advantages.

However, it was not sufficiently convincing to join a campaign just with the UN authorisation. The legacy of Kosovo and Iraq reminded the US that an intervention should be both legal and legitimate, otherwise people would be able to criticise it from either perspective. As Charles Kupchan said, the intervention in Kosovo was illegal but legitimate, because even though there was no UN Security Council Resolution, Kosovo enjoyed broad support in the core world opinion; while the invasion in Iraq was legal but illegitimate, because it received authorisation but did not gain enough support around the world. ${ }^{66}$ In the case of Libya, one of the reasons why the intervention enjoyed legitimacy was NATO. If it had been the US alone, it would have been much more problematic. That was also why Washington insisted on using NATO even though France initially opposed NATO carrying out military support in view of the concern that 'the Alliance has an aggressive image in the Arab World'. ${ }^{67}$

\footnotetext{
${ }^{63}$ Interview with Christopher Chivvis.

${ }^{64}$ A caricature of a despot, Gaddafi personified the type of odious adversary whom all democrats wanted to see defeated. His behaviour has been abominable for decades_ and not only towards his own people. See Dominique Moisi (2011).

${ }^{65}$ At the same time, Russian officials made it clear that serious questions remained, including how a potential nofly zone would operate and who would enforce it. According to Russia's representative at the UN Vitaly Churkin, 'To say we need to act quickly, as fast as possible, but not to provide answers to those fundamental questions is not really helping, it is just beating the air'. He moved on to emphasise that 'You need to be sure any decision the council takes is not going to exacerbate the military-political situation in Libya'. See 'Details Sought on Libya NoFly Plan', The Moscow Times, 16 March 2011.

${ }^{66}$ Interview with Charles Kupchan.

${ }^{67}$ Alan Cowell and Steven Erlanger (2011) 'France Becomes First Country to Recognise Libyan Rebels', The New York Times, 10 March.
} 
Karim Mezran argued that Italy was the first country that demanded a NATO command. ${ }^{68}$ Although France and Britain wanted to go on their own, they found their feet stopped by the Italians who refused to approve either a French or a British command. What France and Britain were truly talking about was to have a combined Anglo-French command outside of the NATO command structure, yet Italy insisted on going through NATO precisely to make it more international on the European side and to keep the US operating within the NATO framework. ${ }^{69}$ Thus, the Europeans had no choice but to require the US help to solve the dilemma, given that the allies had already broken up on this issue: France and Britain wanted to go alone; Italy rejected them to go; and Germany wanted to be neutral. ${ }^{70}$ It became clear that the US had to intervene to complete the mission by dragging in NATO, otherwise Italy would be the incredible cost for the US. There was a desire to preserve the alliance unity, but the alliance was not united on this. In fact, Italy's bid to call for a NATO command mainly rested on its intension to have the US on board, which would guarantee that the allies could win the war. Umberto Bossi, the truculent founder of the Northern League Party was putting pressure on Silvio Berlusconi not to act, because he was badly worried about retaliation due to the close distance between Italy and Libya. ${ }^{71}$ There was a feeling that Gaddafi might unleash some of his agencies to cause terrorist attacks on Italy. On the other hand, a lot of Italians were having Libyan contracts for construction or energy, hence they would lose all those contracts if Gaddafi were going to survive though the allies intervened. The Italians were actually riding the fence, and they could not come down one side or the other. By assessing the full complexity of the situation, the Italians were certainly more cautious than the French and the British, thereby more eager to see Gaddafi lose the war. As a result, the Libyan operation was implemented under the framework of NATO rather than of any bilateral cooperation.

\section{Cost}

Another source of feasibility came from the evaluation of military inputs. Nora Bensahel believed what ultimately convinced President Obama to intervene in Libya was that the mission was very low cost to the US. ${ }^{72}$ The European allies made clear they only wanted US help for the initial air campaign and some intelligence support thereafter. President Obama agreed that the US could have this limited involvement without taking responsibility for what would happen in the country after Gaddafi fell.

\footnotetext{
${ }^{68}$ Interview with Karim Mezran.

${ }^{69}$ Actually at the very beginning, France had set itself apart from some other nations, including the US, by insisting that any military support be authorised by the UN Security Council, but not carried out by NATO, since the Alliance had an aggressive image in the Arab World. The French Foreign Minister Alain Juppe even opposed France resuming full membership in NATO. See Alan Cowell and Steven Erlanger (2011) 'France Becomes First Country to Recognise Libyan Rebels', The New York Times, 10 March.

${ }^{70}$ The French-British forcefulness on Libya did not make all Europeans happy. Germany abstained in the vote at the UN and said it would not take part in military action. It expressed reservations about the no-fly zone proposal, and questioned the enforcement plan. Italy, more dependent than others on Libyan natural gas and oil, reluctantly decided to allow its military bases to be used to enforce a no-fly zone to protect Libyan civilians. See Steven Erlanger (2011) 'France and Britain Lead Military Push on Libya', The New York Times, 18 March. 'Details sought on Libya No-Fly Plan', The Moscow Times, 16 March 2011.

${ }^{71}$ Alessandro Speciale (2011) 'Berlusconi's Libya Conundrum', The Global Post, 22 March.

${ }^{72}$ Interview with Nora Bensahel.
} 
The assessment that it would be done at very low cost turned out to be correct: the total cost to the US, excluding man hours and military personnel who worked on it, was about one billion dollars. It was very little in the scheme of the US defence budget which used to reach 550 billion dollars a year before the US got to the costs of wars in either Afghanistan or Iraq. Why the cost was low, as Bensahel further explained, was because of limited involvement. ${ }^{73}$ It was hard to imagine what the scenario would be for the US to get involved at tremendously high cost. With regard to this, Syria was the comparative case to show why the US decided to take actions in Libya not in other states that were also suffering from humanitarian crises. Although Syria was of greater strategic importance to the US than Libya in terms of chain reaction that resolving the Syrian crisis would also deal a severe setback to Iran's grandiose Middle East ambitions, it did not see Obama actively seek Assad's overthrow. Libya was basically a big flight desert, making military options in Libya much easier. For instance, the Libyan air defences could be quickly taken out from the sky because they were not advanced, thus the allies could have free control of the sky without putting any personnel really on the ground. Syria, quite the opposite, had more effective air force and air defences, which would make enforcing a no-fly zone more difficult. Thus, there was no way to affect the course of conflicts solely from the air, and it would cost hundreds of thousands of troops if ground presence was the only solution, regardless of the fact that Syria was with no guarantee of a good outcome. In other words, the US had limited tools available to effect change in Syria, given 'the capabilities of the Syrian army, its alliance with Hezbollah and Iran, and the fact that the US forces were now engaged in three wars in the Middle East already'. ${ }^{74}$ Moreover, the Libyan rebels had already controlled a good portion of the country, enabling the allies to work with them on the civilian side. Yet unlike in Libya, the US ambassador to Syria reported that 'opposition leaders made clear they did not want US military intervention'. ${ }^{75}$ All these including the prediction that Syria would be of great cost and that involvement might cause anti-US sentiment eventually made military intervention in Syria not a serious option.

\section{Timing}

The US assessment on cost mainly included that Libya was a crisis that really could be handled mostly by the Europeans and that the US could provide a supporting rather than a leading role in another intervention in the area of the Middle East. In addition to the calculation of low cost, there was another factor that further made the Libyan mission militarily feasible: the particular timing when President Obama chose to get involved. James Mann believed that the Obamians, a trusted crew of advisers to President Obama, actually did not expect a military campaign at the beginning, instead, they 'hoped Gaddafi might behave like other Middle Eastern leaders in the early weeks of the Arab Spring, either stepping aside like Mubarak or announcing

\footnotetext{
73 Ibid.

${ }^{74}$ Martin Indyk, Kenneth Lieberthal, and Michael O’Hanlon (2012) p. 173.

${ }^{75}$ Ibid.
} 
some immediate reforms like Jordan's King Abdullah'. ${ }^{76}$ Yet that was soon proved to be a misjudgement. What finally boosted the US move was when Gaddafi talked about going house to house in Benghazi to kill people like rats. The estimated number of innocent civilians who would be killed if that happened would be tens of thousands. To have that kind of slaughter undertaken with international community completely unable to do anything would be a real blemish on not just the US but also the whole world. Samantha Power later reflected, 'We were trying to convince Gaddafi to act with restraint and moderation, but he had already, right from day one, decided to crush this thing. He was taking the other path, the non-Tunisia choice. ${ }^{77}$ Although it is true that NATO allies and the international community cannot prevent every humanitarian disaster or prevent all the political misleads of some leaders, there are instances where they can do something about it. According to Obama's speeches delivered in March, Libya was exactly the case where the international community had the capacity to achieve some goals. It was not about putting a risk higher level of interests, but an opportunity to work with allies and partners to realise an outcome in a reasonable amount of time. Moreover, Libya was actually regarded as an easy case because there was no leader like Gaddafi who truly enjoyed no regional affection. ${ }^{78}$ When Gaddafi was talking about 'purge' that would proceed 'room by room' and 'individual by individual', it was truly believed that he was desperate to do this. ${ }^{79}$ Mindful that Gaddafi was a threat to not only his own people but also the region as a whole, the consensus among international community became unprecedentedly apparent that 'Gaddafi must go and go for good' ${ }^{80}$ Meanwhile, the debate over what the US should do also changed dramatically as regime forces approached Benghazi, for the possibility seemed to become more and more likely that there would be some massive civilian casualties because of regime attack on Benghazi. That really changed the tone of the debate in the US and a lot of objections to intervention were more or less pushed aside as the dynamic sound ground changed. As a result, the pace of decision-making was forced to accelerate when the Libyan military started moving incredibly fast.

Once the UN Security Council Resolutions, the regional organisation, and the Arab League had justified on the necessary means, all political elements with respect to the legal basis for intervention were appropriately addressed. Moreover, most of the European allies agreed that Libya was the place NATO could act to prevent humanitarian catastrophe within the norms of international law, even though Germany, Poland and some others did not choose to contribute. Further, the potential fall of Benghazi made the Libyan crisis rise above the bar as a humanitarian emergency,

\footnotetext{
${ }^{76}$ James Mann (2012) p.283.

${ }^{77}$ Ibid.

${ }^{78}$ Preventing Gaddafi from rebuilding the wall of fear that fell in Tunisia and Egypt was essential if the 'Arab Spring' was not to be succeeded by a new winter of discontent. See Dominique Moisi (2011).

79 OSC Report GMP20110316950075, 'Statement on Libyan TV Says Gaddafi Forces Await "Zero Hour"” To Retake Benghazi', 16 March 2011, and OSC Report GMP20110317676005.

80 'Libya: Obama, Cameron and Sarkozy Vow Gaddafi Must Go', BBC News, 15 April 2011.
} 
urging the US to get involved at this particular timing. When all those came together, it became quite possible for the Obama Administration to take actions.

\section{Military capability}

In addition to the low cost and the particular timing, Washington also took the evaluation of military capability into account when making decision on Libya. There were some people like Kori Schake, who doubted whether the Europeans were really incapable of tackling Gaddafi on their own. By considering that 'Libya spent only \$1 billion on its military in the year before the rebels and NATO militaries felled Muammar Gaddafi_— that is around 2 percent of the UK's defence budget', he argued that 'Britain's superb military alone could probably have found a way to succeed' ${ }^{81}$ In terms of pure balance of power, the British military was much more powerful than the Libyan military, however, when it came to this specific operation, specific capabilities rather than the overall strength would play a more effective role. First of all, in order to unfold the operation, the Libyan air defence network had to be taken down otherwise the pilots from any country would be at great risk. Frankly, besides the US, the ability to defeat the air defence system was something right now no European country or any other country in the world could do. For example, the US had vast piles of air-launched cruise missiles that were vital to create a no-fly zone in Libya, while the British only had very small reserves. Hence on this specific cruise missiles, Britain run out very quickly in the campaign, which dramatically decreased its capability to force the capitulation of the dictator. Hence, for the purpose of guaranteeing that the allies would not fail, the US ultimately decided to intervene as the cruise missiles provider who could just stand off either from sea or air to attack tanks and aircrafts. The reason why the Americans agreed to at minimum come for the first week to ten days of the air operation to knock put Gaddafi's air force and radar was mainly because that no European country, or even the collection of European countries, could have done that. In short, it was not the British in aggregate terms that did not have more powerful military than Libya, but they just did not have the right technology and the right capability to implement the mission.

With respect to how the campaign was truly carried out, Robert Gates complained that 'the mightiest military alliance in history is only 11 weeks into an operation against a poorly armed regime in a sparsely populated country. Yet many allies are beginning to run short of munitions, requiring the US, once more, to make up the difference' ${ }^{82}$ The gap between Washington and European capitals in terms of military capability was not build in a day. ${ }^{83}$ In other words, it would be unrealistic to expect those European allies to take the full burden or to stop relying on US assistance immediately. Moreover, in the case of Libya, the US actually had a long history with Gaddafi dating back to the 1980s when the Regan Administration bombed Tripoli and

\footnotetext{
${ }^{81}$ Kori Schake (2012) 'US Retrenchment Is Right And Overdue', in Tomas Valasek (ed.), All Alone? What US Retrenchment Means For Europe And NATO, Centre for European Reform, p. 9.

${ }^{82}$ Ian Traynor (2011).

${ }^{83}$ For more information, see Appendix 1 'Armed Forces__ Annual Strength'.
} 
Benghazi in retaliation for the attack on a West Berlin nightclub that killed 2 American servicemen and injured $79 .{ }^{84}$ Viewing Libya as 'low-hanging fruit', the US was basically more experienced than those European countries to fight against Gaddafi. Therefore, based on the fact that the US was still indispensible in providing some critical military assistance to guarantee a victory, the Obama Administration finally decided to move forward and fight together with its allies.

\section{Why did the US transfer the Libyan mission to NATO and start 'leading from behind'?}

Since 19 March, coalition military operations under the auspices of the US-led Operation Odyssey Dawn (OOD) had achieved the objective of setting up a no-fly zone over Libya, laying a solid foundation for transferring the Libyan mission to NATO. The transition from the US-led OOD to the NATO-led Operation Unified Protector (OUP) thereafter went seamlessly. ${ }^{85}$ NATO allies reached a unanimous agreement on 27 March to direct NATO to assume command and control of the civilian protection. ${ }^{86}$ The next day, President Obama and his team provided an update on accomplishments to date, including the full transfer of enforcement of the no-fly zone to NATO. ${ }^{87}$

Ever since the end of Cold War, the US has played a dominant role in almost every military intervention around the world. Even 'President Obama has hardly been shy about the projection of American power. Indeed, he oversaw a "surge" of US troops into Afghanistan and has dramatically ramped up the use of drone strikes to combat militant extremists. ${ }^{88}$ However, in the case of Libya, the US was, for the first time, not predisposed to the assertive and excessive use of military force, instead, it was perceived as 'leading from behind'. ${ }^{89}$ The phrase certainly was not what the President or his advisers had ever mentioned, in fact, it was seized on in the media by unknown journalists. But it became widely accepted even in the official assessment on Libya military campaign. ${ }^{90}$ Compared with Kosovo, Afghanistan and Iraq where the US was directing or leading in a very obvious way, Libya saw the US declining to play a dominant role. James Lindsay argued that the reason why both President Clinton and President Obama tried to minimise the visible level of the US military involvement abroad was precisely because intervention had become 'the worst choice and the

\footnotetext{
${ }^{84}$ Edward Schumacher (1986/87) 'The United States and Libya', Foreign Affairs.

85 'NATO Transfer of Command is on Track', NATO, 29 March 2011.

${ }^{86}$ On 24 March 2011, NATO allies decided to enforce the no-fly zone over Libya. At that moment, it was certain that there would be a coalition operation and a NATO operation but NATO allies were still considering whether NATO should take on a broader responsibility in accordance with the UN Security Council resolution. See 'NATO Secretary General's Statement on Libya No-Fly Zone', NATO, 24 March 2011. On March 27, 2011, NATO allies decided to take on the whole military operation in Libya. The goal was to 'protect civilians and civilian-populated areas under threat of attack from the Gaddafi regime'. 'NATO will implement all aspects of the UN Resolution. Nothing more, nothing less'. See 'Statement by NATO Secretary General Anders Fogh Rasmussen on Libya', NATO, 27 March 2011.

${ }^{87}$ President Obama (2011) Remarks by the President in Address to the Nation on Libya, 28 March.

${ }^{88}$ Charles Kupchan (2012) 'A Still-Strong Alliance', Policy Review, No. 172, 30 March.

${ }^{89}$ Charles Krauthammer (2011) 'The Obama Doctrine: Leading From Behind', The Washington Post, 28 April.

${ }^{90}$ Michael Boyle (2011) 'Obama: "Leading From Behind” on Libya', The Guardian, 27 August. Leslie Gelb (2013) 'In Defence of Leading From Behind', Foreign Policy, 29 April.
} 
worst necessity' both in Kosovo and Libya. ${ }^{91}$ In the case of Libya, if the US led from the front rather than led from behind, Gaddafi would have gone sooner and there would have been fewer deaths, yet how could the President deal with the following public condemnation of intervention? How could the President persuade those opponents who were extremely concerned that the US would sink into another 'quagmire' as in Afghanistan and Iraq? According to the Gallup poll conducted on 29 March 2011, only 10\% of Americans said the US should take the lead role in Libya, while the plurality, $36 \%$, favoured a minor role for the US, and $22 \%$ thought the US should withdraw entirely. ${ }^{92}$ No one knew how precious the opportunity cost would have been if the US decided to lead from the front, but certainly the President would have faced tougher objections, threatening to shrink or even abolish the pursuit of intervention. Those domestic concerns could be addressed by applying the framework of NATO, which could help obscure the essential role of Washington. Mindful of what happened in the Iraq war where the Bush Administration's unilateral proposal of global War on Terror resulted in a dramatic increase in transatlantic tension, it was politically important to transfer the Libyan mission to NATO and start 'leading from behind', because on one hand, public support for intervention would be secured and on the other hand, criticism about overextending US military would fall of itself. More importantly, 'leading from behind' was in line with Obama's grand strategy on 'multilateral retrenchment' which was designed to 'curtail the United State's overseas commitments, restore its standing in the world, and shift burdens onto global partners' ${ }^{93}$ President Obama was elected to end the war in Iraq, who also placed great importance on multilateralism. He saw it as an opportunity to create more political benefits to the US by handing the Libyan mission to NATO, which would be characterised as a multilateral effort rather than the US acting unilaterally.

Paula Newberg introduced an interesting explanation about 'leading from behind' that the US could only provide moral rather than material support. ${ }^{94}$ Yet the US contribution was not really 'constrained'. In theory, 'leading from behind' allowed the US to limit its dominant role, yet in practice, it was still the US military that provided the most capabilities. According to Ivo Daalder, the US Ambassador to NATO, in the initial operation which was conducted in a coalition format before NATO came in, the US was by far and away the dominate military contributor to the operation, providing all kinds of assets in order to make it possible. ${ }^{95}$ After 10 days operation, the US stepped back and NATO took over. Although the full transfer of command to NATO was planning to be completed just in several days, Robert Gates was not able to give a firm deadline for just how long US involvement would last. ${ }^{96}$ Thus, even in the

\footnotetext{
${ }^{91}$ Interview with James Lindsay.

${ }^{92}$ Lydia Saad (2011) 'Americans Resist A Major US Role in Libya', Gallup Politics, 29 March.

${ }^{93}$ Daniel Drezner (2011).

${ }^{94}$ Interview with Paula Newberg, the Marshall B. Coyne Director of the Institute for the Study of Diplomacy at Georgetown University, 05 July 2012.

${ }^{95}$ Ivo Daalder and James Stavridis (2011) 'NATO's Success in Libya', The New York Times, 30 October. Ivo Daalder and James Stavridis (2012) 'NATO's Victory in Libya: The Right Way to Run An Intervention', Foreign Affairs.

${ }_{96}^{96}$ Elisabeth Bumiller and Thom Shanker (2011).
} 
second part of operation, Washington continued to play a significant role behind scenes, leaving the American Navy and Air Force very much involved in enforcing a no-fly zone over Libya. For example, to minimise civilian casualties, it was required to obtain a high degree of surveillance, the vast majority of which was provided by the US. Generally, it was true that the US was not playing a dominant role in Libya, however, it did not mean that the US was not playing a significant role there. Although it were the Europeans who flew large number of combat sorties, the US support was absolutely essential, particularly in the area of the intelligence and surveillance. Further, as Nora Bensahel identified, another area where US assistance was also greater was in air-refuelling, which the Europeans had low capability of. ${ }^{97}$ The US offered this decisive backing to some small countries that were flying sorties, particularly to Scandinavia, the Netherlands and Belgium that served to provide position ignitions. Basically, without the US air-refuelling and reconnaissance, there would have been little military effect from the NATO operations, given that the US provided the best bulks of air-refuelling that allowed aircrafts to be on station to complete both the surveillance and strike missions.

Although Washington continued to provide significant and critical support even after transferring the Libyan mission to NATO, the signal came from the strategy of 'leading from behind' was clear that the US would not always play a dominant role and the European allies should shoulder more responsibilities. To send that message around the world was meaningful to the US especially in the context of current economic pressures and domestic US debates about post-War on Terror interventions, but most importantly, it helped the US reconsider its role as a 'global policeman' and redefine the 'American way of war'. Thus whether there was a so-called 'Libyan model' that could be applied to future crisis management became an interesting question.

\section{The so-called 'Libyan model' and the future of NATO}

As a rule of thumb, when the US is involved in a war, it always 'throws enough money, weapons and people at conflicts to guarantee an overwhelming advantage for itself and it also has the technology to do much of the fighting from afar and therefore in relative safety' (though not true of Vietnam). ${ }^{98}$ But the Libyan war did not match this default 'American way of war'. There were many fresh elements that constituted the so-called 'Libyan model'. During the conflict, the US left its European allies to lead, taking on a limited, supporting role for the first time. Even though the Obama Administration made clear it would not allow allies to fail, it contributed only enough assistance to prevent operations from failing, not enough for them to speedily succeed. Nourished by the leading thought that the Libyan war provided a likely blueprint for many future NATO operations, Kori Schake took the Libyan war as 'the clearest

\footnotetext{
${ }^{97}$ Interview with Nora Bensahel.

${ }^{98}$ Kori Schake (2012) p10.
} 
signal to date that the US will not do more, proportionally, than other allies when it, too, faces austerity' ${ }^{99}$ From now on, America will behave like any other ally, sitting out some of NATO's wars, and doing just enough to help other operations to succeed. The US armed forces will no longer automatically make up the difference between NATO's ambitions and European military means. As Ivo Daalder concluded, 'if there ever was a time in which the United States could always be counted on to fill the gaps that may emerge in European defence, that time is rapidly coming to an end'. ${ }^{100}$ Beyond the theoretical dimension, the Obama Administration has declared Libya to be a demonstration of its strategic doctrine: in response to humanitarian crisis, the US will work with allies to gain international acceptance for intervention in support of indigenous forces and join a coalition to use military force. It will not play the dominant role in such coalitions. It will not support revolutionary movements without mandates from the United Nations Security Council. ${ }^{101}$

Some scholars such as George Joffe, viewed the US decision on 'leading from behind' as not only a promise that America was happy to see European countries deal with such conflicts as Libya on their own, but also a reminder to its European allies that they should shoulder the responsibility to take all the relevant burdens resulted from their passionate action. ${ }^{102}$ It is true that many European governments have long hoped for a 'European pillar', a defence capability that is less dependent on US support. Ideally, the US retrenchment would certainly increase the likelihood of European countries leading future missions, however, many allies perceived Libya as an unsatisfactory experience. Robert Gates pointed out

While every alliance member voted for the Libya mission, less than half have participated, and fewer than a third have been willing to participate in the strike mission...Frankly, many of those allies sitting on the sidelines do so not because they do not want to participate, but simply because they cannot. The military capabilities simply are not there. ${ }^{103}$

This sad story made NATO's European members rethink about their inability to project force and stability. Yet Tomas Valasek believed that most Europeans seemed to lack in their DNA the sense of global responsibility, which explained their shyness in using military force. The allies seemed to have no interest in fostering their ambition to play a bigger role in their own defence. Instead, they were more satisfied with the current situation that burdens and responsibilities were shifted to the US and that they could just stay calmly under the US security umbrella. But no matter how unwilling European countries were to spend their resources and use military forces, they were unable to find a reasonable excuse to free themselves from the burden-

\footnotetext{
${ }^{99}$ Ibid., p18.

${ }^{100}$ Graig Whitlock (2012) 'NATO Allies Grapple with Shrinking Defence Budgets', The Washington Post, 13 January. Ivo Daalder and James Stavridis (2012).

101 Kori Schake (2012) p19.

${ }^{102}$ Middle East Symposium 'One year on from the Arab Spring?', University of Birmingham, 24 February 2012.

${ }^{103}$ Donna Miles (2011) 'NATO Members Re-evaluate Contributions To Libya', US Fed News, 14 June.
} 
sharing responsibility. Thus, with Washington getting tired of shouldering the unequal division and growing to be more sensitive than ever to free-riding behaviours, the European allies should start playing a more active military role if they wanted NATO to persist. The Libyan war was exactly the beginning of 'the time'. It introduced a new definition of 'European way of war'. It reweighed the military disparity between America and its European allies. It also marked the advent of a new round of debate over the burden-sharing problem.

The 'American way of war' has been the most often cited term when talking about the adversaries that NATO has fought in the past twenty years. Washington enjoys unmatched capability, raising the standard of performance so high that no other country dares to engage even in those military operations for which they have sufficient capability. On one hand, America has never been reluctant to pour such resources as personnel, money and weapons into conflicts; on the other, America has casted a long shadow not only within NATO but also around the world due to its unbeatable strength.

The US has 11 aircraft carrier battle groups; no other nation has more than one. The US also has three times as many modern battle tanks, four times the number of fourthgeneration tactical aircraft (and is already fielding the fifth generation), more than three times as many naval cruisers and destroyers, 19 times as many tanker aircraft and 48 times as many unmanned aerial vehicles as any other country. ${ }^{104}$

As a result, some European allies, who regarded 'unable to perform as perfectly as America does' as 'unable to perform', hesitated to advocate the 'European way of war'. Nonetheless, the risk of fighting without America's weapons was not as terrified as envisaged. The war fought to the European doctrine might bring troops in closer contact with the enemy, inflict more civilian casualties, and last longer, making it harder for the governments to keep public support. But these foreseeable difficulties were less knotty than the potential trouble that might be created if they refused to act without US participation. It was because that the refusal means nothing but those members failed to intervene to protect people from autocratic governments, investigate or even destroy suspect nuclear facilities, and support freedom and democracy taking roots. It became clear that European allies had no better choice than taking necessary actions even without US support.

In fact, the situation was quite promising when taking the evaluation of European militaries into account.

The European allies have a million more troops under arms than the US...Any one of the major European militaries could have defeated any of the adversaries that NATO fought in the past 20 years. In combination, the Europeans' fighting power is more than adequate to

\footnotetext{
${ }^{104}$ Kori Schake (2012) p7.
} 
impose their will even in some of the world's most challenging battlegrounds such as the Middle East. ${ }^{105}$

However, Europe underestimated its own strength for most of the time, relying on the American pledge to defend its allies. Thus, most NATO countries were well below the Alliance's guideline of spending 2\% of GDP on defence. In 2011, only Greece (2.4\%) and UK (2.6\%) spend above the threshold, while the US represents $4.8 \%$ of GDP in its defence budget. Defence spending per capita in the US is nearly double that of any NATO ally, at $\$ 2,062$ per person, followed by Norway $(\$ 1,035)$, UK (\$970), France (\$663) and Denmark (\$635). ${ }^{106}$

It seems that the unequal division between American and European military outputs is more like a self-created obstacle due to the unwillingness of European allies to increase their contributions. But this is not the whole story. The disparity between military capabilities does exist. Taking the Libyan war as an example, although the US took its stance of not playing a leading role, 'it fired nearly all the cruise missiles that destroyed Libya's air defences in advance of allied strike missions, provided the great majority of the aerial tankers and nearly all of the surveillance and electronic warfare elements on which allied fights depended, and flew 25 per cent of all sorties'. ${ }^{107}$ The Libyan operation was illustrative that it could not have been fought in the way it was without the US support. However, this does not mean that the war could not have been fought at all. As is mentioned above, the Libyan defence budget reached only $\$ 1$ billion in the year before Gaddafi failed, which was approximately $2 \%$ of Britain's. No one could really doubt that the European military forces led by Britain and France was unable to force the capitulation of a dictator and find a way to succeed. Thus, the European allies are not unable, but unwilling, to intervene to protect persecuted civilians the same as the US does, removing the veil of the longstanding debate about the burden-sharing problem.

Kori Schake emphasised three new elements that made the current round of burdensharing debate more serious than previous ones. 'First, the major threats to the US are no longer European in origin...Second, US armed forces find coalition warfare more and more difficult and decreasingly helpful... The third and most important reason... is that pressures for austerity are likely to endure, not only in Europe but also in the US. ${ }^{108}$ Others believed that the core variable refers to America's own strategic adjustment----it changes to style itself more as a Pacific than a European power. In the President Obama's 2012 review of military strategy, he expressed the will of focusing on more pressing threats in Asia and the Middle East whilst hoping that Europe would take control of its own security. The President also sent a message to the US allies in

\footnotetext{
105 Ibid., p5

106 'Financial and Economic Data Relating to NATO Defence', NATO, 24 February 2014. 'The Military Balance 2011', International Institute for Strategic Studies. Also see Appendix 2 'Defence Expenditures As A Percentage of Gross Domestic Product'.

${ }^{107}$ Kori Schake (2012) p9.

${ }^{108}$ Ibid., pp.10-11.
} 
Asia that American forces there would grow and new American marines would be deployed. Europe, on the opposite, did not receive any substantive reassurance from the US but a vague promise that 'We're going to continue investing in our critical partnerships and alliances, including NATO, which has demonstrated time and again — most recently in Libya_ — that it is a force multiplier'. ${ }^{109}$ And even worse, the Pentagon's new 'defence strategic guidance' required the US to cut down the maintenance of its troops in Europe while denounced the dissatisfied performance of European forces. ${ }^{110}$ Many of the 80,000 US personnel stationed in Europe would be withdrawn, probably pushing the alliance back to its earlier model that no permanent presence of US forces in Europe was guaranteed. Hence Freddy Gray called Obama 'the Pacific President' who was taking a decisive turn away from Europe in his second term. ${ }^{111}$

The current US foreign policy tends to focus more on the Asian Pacific region, yet it does not ignore Europe completely. On 16 February 2013, President Obama gave the annual state-of-the-union message to Congress, announcing that America and the EU would begin talks to create a transatlantic free-trade zone. ${ }^{112}$ This proposal was not new, but reemphasised how top Europe ranks on the list of American foreign policy. Furthermore, in terms of Obama's recent foreign policy vision outlined on 28 May 2014, it seems that the US has refocused its attention on Europe: in addition to the remarkable claim that 'America must always lead on the world stage', Obama also emphasised the importance of mobilising allies and partners to take collective action, which sent a message to European countries in particular that the US would strengthen its cooperation with them in dealing with the Syrian and Ukrainian crises. ${ }^{113}$ Moreover, Obama pledged a billion-dollar military programme of reinforcements in Europe in the wake of the Ukrainian crisis, reaffirming US commitment to Eastern Europe and showing US determination to 'review its force presence in Europe in the light of the new security challenges on the continent'. ${ }^{114}$ So far, the Air Force Aviation Detachment (Av-Det) in Poland has got a continuous US presence, with 10 US Air Force members stationed at Lask Air Base. ${ }^{115}$ This is certainly in conformity with the US promise to boost the military contingent in Europe, but the question remains as to how seriously can US commitment to Europe be taken, given that after all, Obama's 'European reassurance initiative' was not about stationing US or NATO troops permanently in Poland or the Baltic states. ${ }^{116}$ Whether Washington is truly 'refocusing' its attention on Europe is ambiguous, nonetheless US

\footnotetext{
${ }^{109}$ President Obama (2012) Remarks by the President on the Defence Strategic Review, 05 January.

110 'Sustaining US Global Leadership: Priorities for $21^{\text {st }}$ Century Defence', The White House, 03 January 2012.

${ }^{111}$ Freddy Gray (2013) 'The Pacific President', The Spectator, 19 January.

112 'The State of the Union: A House Divided', The Economist, 16 February 2013.

113 Tom Cohen, Jim Acosta and Kevin Liptak (2014) 'Obama Outlines Foreign Policy Vision of "Might and Right”, $C N N, 29$ May.

${ }^{114}$ Ian Traynor (2014) 'Obama Pledges \$1bn to Boost Military in Europe in Wake of Ukraine Crisis', The Guardian, 03 June.

115 'US Forces in Poland Strengthen NATO Partnerships During Aviation Rotation', Spangdahlem Air Base, 03 June 2014.

116 'Poland and America: Troops In', The Economist, 07 June 2014.
} 
commitment to NATO is strengthened under current circumstances, regarding the need to show a strong response to Russia's aggression.

But it is not easy to assure a positive outcome of a reinvigorated transatlantic relationship that is based on the future rather than the past. As Mark Webber et al. point out, the challenge to NATO's persistence nowadays is whether it can service its two motors: its principle of purpose and its principle of function. ${ }^{117}$ The Ukraine crisis has at least given NATO a purpose. But the good functioning of NATO has not been guaranteed, given that as a consequence of the Alliance's operations 'NATO is becoming solely dependent on the US nuclear guarantee'. ${ }^{118}$ Such a situation reinforces the burden-sharing argument that is again emerging. ${ }^{119}$ Most importantly, the inherent NATO problems should be tackled. For the US commitment to the Alliance, what NATO operations discovered was constantly similar: the most likely factor that might terminate US commitment to the Alliance comes from the inherent problem of burden-sharing which has remained unresolved since the establishment of NATO. And the problem will possibly be repeated in Ukraine again if NATO ultimately get involved, given that NATO members have already been in disagreement: 'Germany is more circumspect about sanctions against Russia, and wants NATO to keep to its 1997 agreement. France is at loggerheads with Poland (and America) over its plans to sell Russia two amphibious assault ships. ${ }^{120}$ Some people might argue that the NATO problems had existed even before the 1990s and no serious consequence had been caused thus far. Yet the situation today is unprecedentedly complicated, which will probably bring an earthshaking change to the transatlantic relationship if it is not taken seriously. In short, with respect to the growing US preference for the 'Pivot to Asia' strategy, it becomes certain that 'unless something changes, NATO will end up just doing less with less'. ${ }^{121}$

In the long run, NATO's future depends in large part on whether the European allies find their willingness to play a role commensurate with their strength. But the process of transformation will take a long time in practice. Therefore, in the short run, a compromising mechanism among NATO members will prevail, requiring the a la carte approach' to be accepted as part of how NATO works. One lesson learned from Libya was that not all members would join all future NATO operations (only 8 out of 28 allies followed the French and UK lead in bombing Libya). NATO members, who are no longer unified by a common enemy like the Soviet Union, begin to worry about different threats. And it becomes harder for allies to agree to fight wars that they care unequally passionately. Thus, NATO should allow some members to stay on the sidelines and contribute only symbolically (give their approval for NATO to unfold

\footnotetext{
117 Webber, Hallams, and Smith (2014) 773-793.

118 Dorman (2012) 'NATO’s 2012 Chicago Summit: A Chance to Ignore the Issues Once Again?', International Affairs, Vol. 88, No. 2, 311.

119 Yost (2009) 'Assurance and US extended Deterrence in NATO', International Affairs, Vol. 85, No. 4, 755-780.

120 'Poland and America: Troops In', 2014.

121 'NATO's Sea of Troubles', The Economist, 31 March 2012.
} 
the operation legitimately), rather than demanding every ally to take an effective role in NATO's every military mission. Some people are opposed to the 'division of labour', for it would upgrade the risk of moral hazard in future military operations. However, this compromising solution is still better than the alternative that NATO members fail to launch, let alone accomplish missions altogether because some allies refuse to participate. Moreover, with regard to the strong possibility that Washington would lead fewer operations in the future, European allies should design a more agreeable rule of transatlantic cooperation in specific missions. They should take the initiative to make their military plans more explicit about how much support they expect from the US, and negotiate with the US on how and what kind of assistance the US should provide during operations. In short, to see NATO persist and capable of dealing with more issues in the future, European countries should make more contributions to the Alliance, and to the sustainment of a healthy relationship with the US. 
Appendix 1: Armed forces_—annual strength

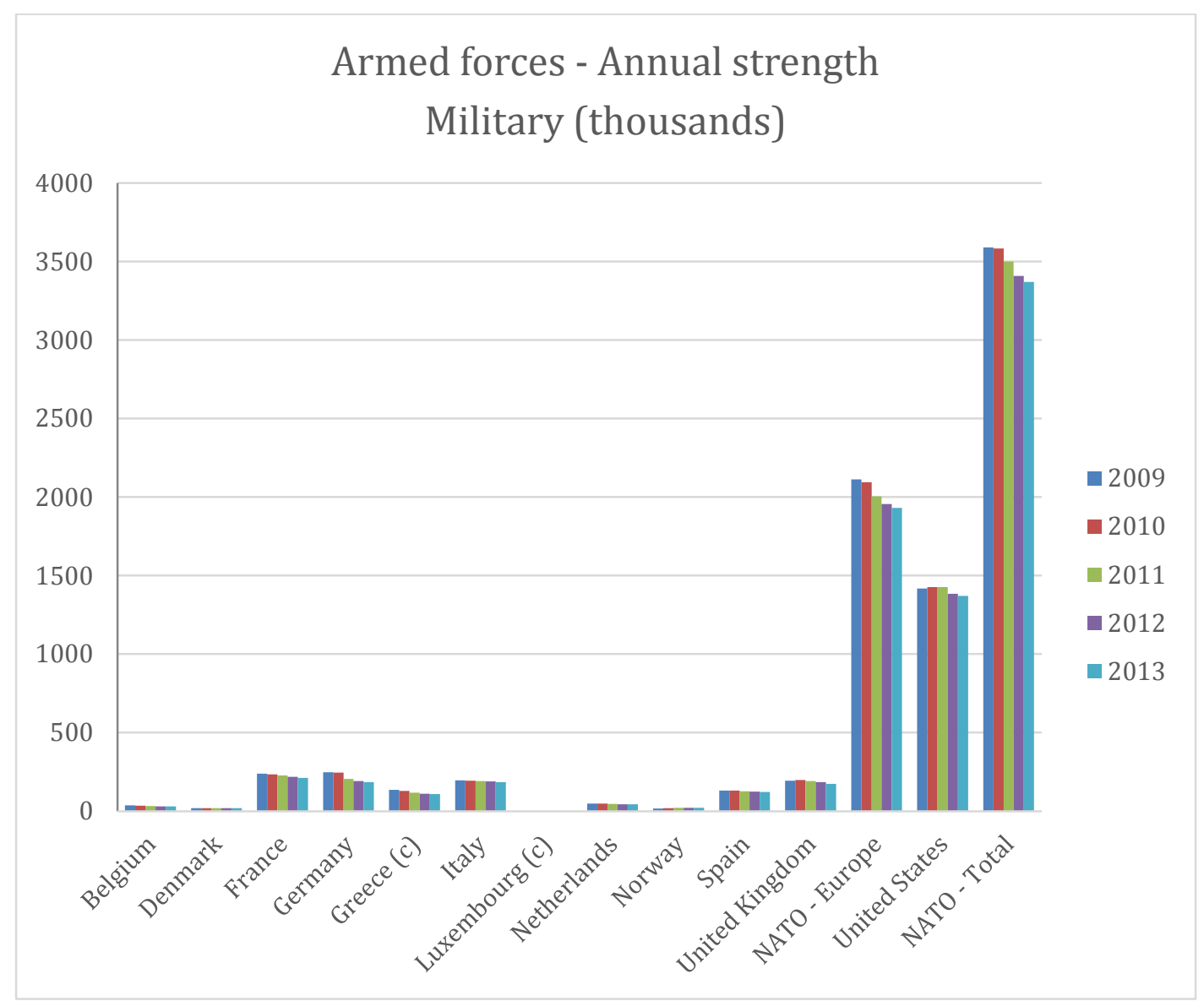


Appendix 2: Defence expenditures as a percentage of gross domestic product

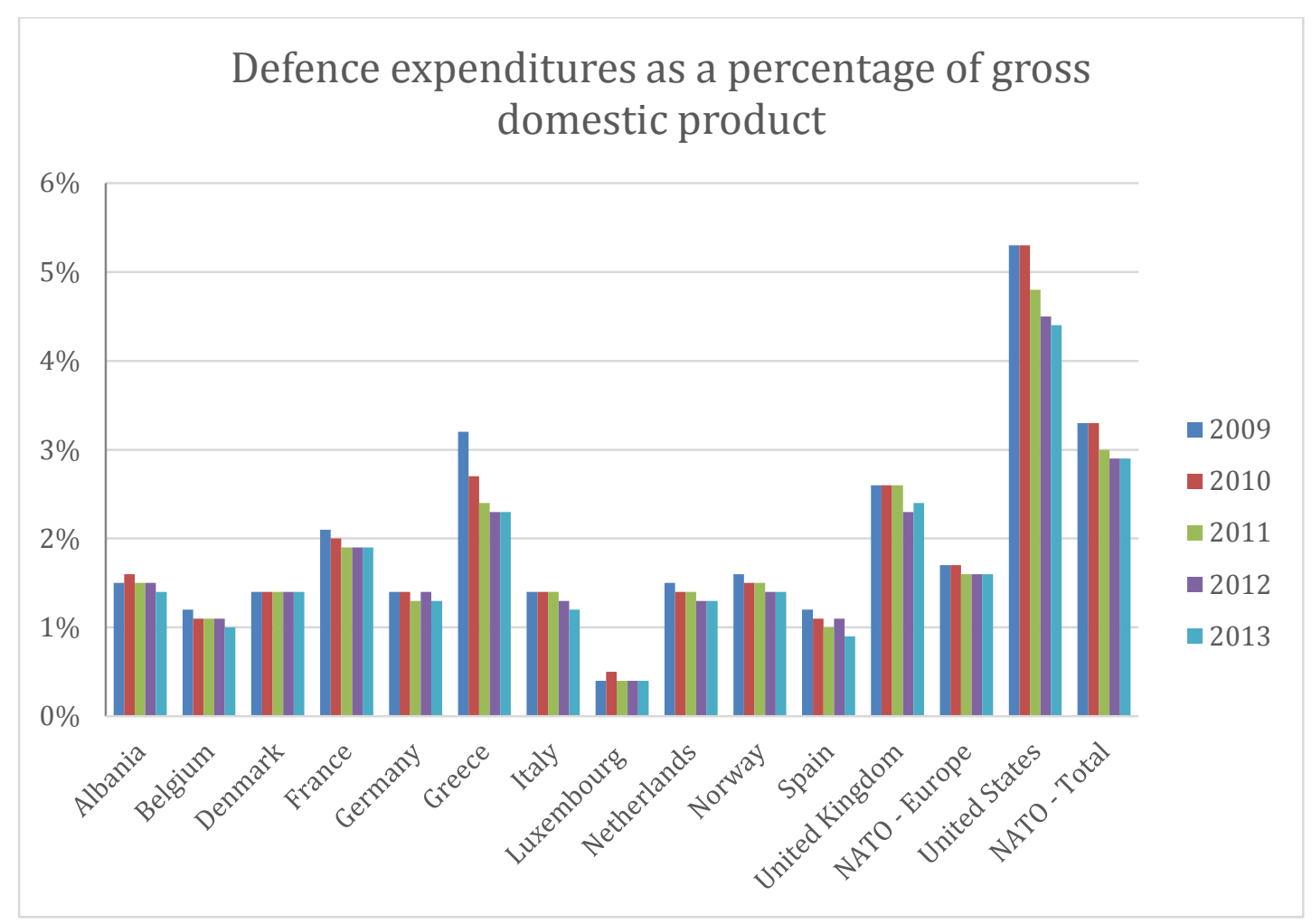




\section{Bibliography:}

ABC News Video (2007) Hillary: No 'Formal' Role for Bill [online]. Available from: http://abcnews.go.com/ThisWeek/video?id=4066505 [Accessed 31 December 2007].

Abrams, E. (2011) 'Mr. Gates Oversteps', The Council on Foreign Relations, 31 March [online]. Available from: http://blogs.cfr.org/abrams/category/libya/ [Accessed 13 March 2013].

ABC News (2011) Time to Focus on Nation Building Here at Home [online]. Available from: http://abcnews.go.com/Politics/video/president-obama-addressesextending-promise-america-nation-building-at-home-politics-13908688 [Accessed 22 June 2011].

BBC News (2011) 'Libya: Benghazi Clashes Deadly_Witnesses', 18 February [online]. Available from: http://www.bbc.co.uk/news/world-africa-12506787 [Accessed 21 October 2011].

BBC News (2011) 'Libyan Leader Muammar Gaddafi Appears on State TV', 22 February [online]. Available from: http://www.bbc.co.uk/news/world-africa-12533069 [Accessed 15 May 2012].

Barnes, J. (2011) 'US Wary Of Libya Role', Wall Street Journal, 12 March.

BBC News (2011) 'Libya: Obama, Cameron and Sarkozy Vow Gaddafi Must Go', 15 April [online]. Available from: http://www.bbc.co.uk/news/world-africa-13089758 [Accessed 09 August 2012].

Boyle, M. (2011) 'Obama: "Leading From Behind" on Libya', The Guardian, 27 August [online]. Available from: http://www.theguardian.com/commentisfree/cifamerica/2011/aug/27/obama-libyaleadership-nato [Accessed -3 February 2012].

Speciale, A. (2011) 'Berlusconi’s Libya Conundrum', Global Post, 22 March [online]. Available from: http://www.globalpost.com/dispatch/news/regions/europe/italy/110322/silvioberlusconi-libya [Accessed 05 May 2012].

Barnes, J. and Levinson, C. (2011) 'US Drones Hit Targets In Libya', Wall Street Journal, 25 April.

Bumiller, E. and Shanker, T. (2011) '2 Cabinet Officials Say US Isn’t Likely to Arm 
Libyans', The New York Times, 31 March [online]. Available from: http://www.nytimes.com/2011/04/01/world/africa/01military.html [Accessed 16 March 2013].

CNN (2011) "Clinton to Libya: End "Unacceptable Bloodshed", 22 February [online]. Available from: http://edition.cnn.com/2011/POLITICS/02/21/libya.us.reaction/?hpt=T2 [Accessed 17 May 2013].

Cowell, A. and Erlanger, S. (2011) 'France Becomes First Country to Recognise Libyan Rebels', The New York Times, 10 March [online]. Available from: http://www.nytimes.com/2011/03/11/world/europe/11 france.html?_r=0 [Accessed 04 May 2012].

Cooper, H. and Myers, S. (2011) 'Obama Takes Hard Line With Libya after Shift by Clinton', The New York Times, 18 March [online]. Available from: http://www.nytimes.com/2011/03/19/world/africa/19policy.html [Accessed 19 June 2012].

Crowley, M. (2011) 'Susan Rice, Samantha Power, Rwanda and Libya', Time, 24 March [online]. Available from: http://swampland.time.com/2011/03/24/susan-ricesamantha-power-rwanda-and-libya/ [Accessed 20 February 2012].

Calabresi, M. (2011) 'Susan Rice: A Voice for Intervention', Time, 24 March [online]. Available from: http://content.time.com/time/magazine/article/0,9171,2061224,00.html [Accessed 24 March 2012].

Cohen, T., Acosta, J. and Liptak, K. (2014) 'Obama Outlines Foreign Policy Vision of "Might and Right", CNN, 29 May [online]. Available from: http://edition.cnn.com/2014/05/28/politics/obama-west-point-foreign-policy/ [Accessed 10 June 2014].

De Villepin, D. (2003) 'Statement by Dominique de Villepin to the UNSC', Foreign Policy, 14 February 2003 [online]. Available from: http://www.foreignpolicy.org.tr/documents/villepin_140203_p.htm [Accessed 13 November 2012].

Drezner, D. (2011) 'Does Obama Have a Grand Strategy?: Why We Need Doctrines in Uncertain Times', Foreign Affairs, July/August Issue.

Daalder, I. and Stavridis, J. (2011) 'NATO's Success in Libya', The New York Times, 30 October [online]. Available from: http://www.nytimes.com/2011/10/31/opinion/31iht-eddaalder31.html? r=0 [Accessed 
04 January 2012].

Daalder, I. and Stavridis, J. (2012) 'NATO's Victory in Libya: The Right Way to Run An Intervention', Foreign Affairs [online]. Available from: http://www.foreignaffairs.com/articles/137073/ivo-h-daalder-and-james-gstavridis/natos-victory-in-libya [Accessed 10 May 2012] [Accessed 03 March 2013].

Daalder, I. and Stavridis, J. (2012) 'NATO's Victory in Libya', Foreign Affairs [online]. Available from: http://www.foreignaffairs.com/articles/137073/ivo-hdaalder-and-james-g-stavridis/natos-victory-in-libya [Accessed 10 May 2012].

Erlanger, S. (2011) 'France and Britain Lead Military Push on Libya', The New York Times, 18 March [online]. Available from: http://www.nytimes.com/2011/03/19/world/africa/19europe.html [Accessed 07 March 2013].

Entous, A. and Johnson, K. (2011) 'US Weights More Libya Moves', Wall Street Journal, 02 April.

Gergen, D. (2011) 'What Is Obama's Endgame in Libya?', CNN, 21 March [online]. Available from: http://edition.cnn.com/2011/OPINION/03/20/gergen.washington.libya/ [Accessed 12 March 2013].

Gray, F. (2013) 'The Pacific President', The Spectator, 19 January [online]. Available from: http://www.spectator.co.uk/features/8825701/the-pacific-president/ [Accessed 07 May 2013].

Gelb, L. (2013) 'In Defence of Leading From Behind', Foreign Policy, 29 April [online]. Available from: http://www.foreignpolicy.com/articles/2013/04/29/in_defense_of_leading_from_behin d [Accessed 05 August 2013].

International Institute for Strategic Studies (2011) The Military Balance 2011.

Indyk, M., Liberthal, K. and O'Hanlon, M. (2012) Bending History: Barack Obama's Foreign Policy, Washington: Brookings Institution Press.

Interview with Newberg, Paula, the Marshall B. Coyne Director of the Institute for the Study of Diplomacy at Georgetown University, 05 July 2012.

Interview with Mezran, Karim, Senior Fellow at the Atlantic Council, 09 July 2012.

Interview with Litwak, Robert, Vice President for Scholars and Director of 
international Security Studies at the Woodrow Wilson Center, 10 July 2012.

Interview with Lindsay, James, Senior Vice President, Director of Studies and Maurice R. Greenberg Chair at the Council on Foreign Relations, 10 July 2012.

Interview with Flanagan, Stephen, the Henry A. Kissinger Chair in Diplomacy and National Security at the Center for Strategic and International Studies, 10 July 2012.

Interview with Lieber, Robert, Professor of Government and International Affairs at Georgetown University, 11 July 2012.

Interview with Heydemann, Steven, Senior Adviser for Middle East Initiatives at the United States Institute of Peace, 16 July 2012.

Interview with Chivvis, Christopher, Senior Political Scientist at RAND, 16 July 2012.

Interview with Bensahel, Nora, Deputy Director of Studies and Senior Fellow at the Center for A New American Security, 16 July 2012.

Interview with Kupchan, Charles, Whitney Shepardson Senior Fellow at the Council on Foreign Relations, 17 July 2012.

Interview with Ambassador Stephens, Kathleen, 18 July 2012.

Jackson, D. (2011) 'One Reason for Obama's Decision on Libya: Rwanda', The Oval [online]. Available from:

http://content.usatoday.com/communities/theoval/post/2011/03/one-reason-forobamas-decision-on-libya-rwanda/1\#.UFdXGEKhRmA [Accessed 24 March 2011].

Joffe, G. (2012) Middle East Symposium 'One year on from the Arab Spring?', University of Birmingham, 24 February.

Kupchan, C. (2012) 'A Still-Strong Alliance', Policy Review, No. 172 [online]. Available from: http://www.hoover.org/publications/policy-review/article/111956 [Accessed 12 August 2012].

Loschky, J. (2012) 'Opinion Briefing: Libyans Eye New Relations With the West', Gullup Politics, 13 August [online]. Available from: http://www.gallup.com/poll/156539/Opinion-Briefing-Libyans-Eye-New-RelationsWest.aspx [Accessed 07 May 2014].

Moisi, D. (2011) 'France Had A Duty to Intervene in Libya', The Guardian, 23 March [online]. 
http://www.theguardian.com/commentisfree/2011/mar/23/france-libya-sarkozy [Accessed 11 March 2012].

Miller, J. (2011) 'Defence Secretary: Libya did not pose threat to US, was not "vital national interest" to intervene', $A B C$ News [online]. Available from: http://abcnews.go.com/International/defense-secretary-libya-pose-threat-us-vitalnational/story?id=13231987\# [Accessed 27 March 2011].

Miles, D. (2011) 'NATO Members Re-evaluate Contributions To Libya', US Fed News, 14 June.

Mann, J. (2012) The Obamians, Penguin Group, USA.

NATO (2011) 'NATO Secretary General's Statement on Libya No-Fly Zone', 24 March [online]. Available from: http://www.nato.int/cps/en/SID-000D52C279D96027/natolive/news 71763.htm?selectedLocale=en [Accessed 09 January 2012].

NATO (2011) 'NATO Transfer of Command is on Track', 29 March [online]. Available from: http://www.jfcnaples.nato.int/page16750038.aspx [Accessed 09 January 2012].

NATO (2011) NATO to Maintain High Operational Tempo As Long As Necessary in Libya [online]. Available from: http://www.nato.int/cps/en/natolive/news 72549.htm [Accessed 14 April 2011].

NATO (2014) 'Financial and Economic Data Relating to NATO Defence', 24 February.

OSC Report GMP20110316950007 (2011) Libyan Army Announces Advance on Benghazi, 16 March.

OSC Report GMP20110316950075 (2011) Statement on Libyan TV Says Gadhafi Forces Await 'Zero Hour' To Retake Benghazi, 16 March.

OSC Report GMP20110317676005 (2011) Al-Gadhafi Asks Benghazi People To Abandon 'Traitors' Vows to 'Confront' NATO, 17 March.

President Obama (2008) 'Obama's Speech on Iraq', Council on Foreign Relations, 19 March [online]. Available from: http://www.cfr.org/elections/obamas-speech-iraqmarch-2008/p15761 [Accessed 09 September 2013].

President Obama (2008) 'Obama's Remarks on Iraq and Afghanistan', The New York Times, 15 July [online]. Available from: http://www.nytimes.com/2008/07/15/us/politics/15text-obama.html?pagewanted=all 
[Accessed 09 September 2013].

President Obama (2010) 'Address to the Nation on the End of Combat Operations in Iraq', 31 August [online]. Available from: http://www.presidency.ucsb.edu/ws/index.php?pid=88362\&st $=\& s t 1=[$ Accessed 10 September 2013].

Parrish, K. (2011) 'Gates: NATO’s Libya Plans To Include Military Options', US Fed News, 10 March.

Perez, E. (2011) 'Brennan: US Wary of Terrorism in Libya', The Wall Street Journal, 18 March [online]. Available from: http://blogs.wsj.com/washwire/2011/03/18/brennan-u-s-wary-of-terrorists-in-libya/ [Accessed 08 June 2013].

President Obama (2011) This Violence Must Stop [online]. Available from: http://www.whitehouse.gov/blog/2011/02/23/president-obama-speaks-turmoil-libyaviolence-must-stop [Accessed 23 February 2011]

President Obama (2011) Remarks by the President on the Situation in Libya, 18 March [online]. Available from: http://www.whitehouse.gov/the-pressoffice/2011/03/18/remarks-president-situation-libya [Accessed 12 January 2012]

President Obama (2011) Letter from the President Regarding the Commencement of Operations in Libya, 21 March [online]. Available from http://www.whitehouse.gov/the-press-office/2011/03/21/letter-president-regardingcommencement-operations-libya [Accessed 20 February 2012].

President Obama (2011) Remarks by the President in Address to the Nation on Libya, 28 March [online]. Available from: http:/www.whitehouse.gov/the-pressoffice/2011/03/28/remarks-president-address-nation-libya [Accessed 12 February 2012].

President Obama (2011) Obama Libya Speech: US 'Interests and Values' at Risk, 28 March [online]. Available from: http://www.whitehouse.gov/photos-andvideo/video/2011/03/28/president-obama-s-speech-libya [Accessed 12 February 2012].

President Obama (2011) Remarks by the President on the Middle East and North Africa, 19 May [online]. Available from: http:/www.whitehouse.gov/the-pressoffice/2011/05/19/remarks-president-middle-east-and-north-africa [Accessed 19 March 2012].

President Obama (2012) Remarks by the President on the Defence Strategic Review, 
05 January [online]. Available from: http://www.whitehouse.gov/photos-andvideo/video/2012/01/05/president-obama-speaks-defense-strategic-review\#transcript [Accessed 07 February 2012].

Rogin, J. (2011) 'How Obama Turned on A Dime Toward War', Foreign Policy, 18 March [online]. Available from: http://thecable.foreignpolicy.com/posts/2011/03/18/how obama turned on a dime t oward_war [Accessed 12 May 2012].

Schumacher, E. (1986/87) 'The United States and Libya', Foreign Affairs [online]. Available from: http://www.foreignaffairs.com/articles/41701/edwardschumacher/the-united-states-and-libya [Accessed 04 February 2012].

Sky News (2011) 'Death Toll in Libya Protest "Hits 120", 19 February [online]. Available from: http://news.sky.com/story/837913/death-toll-in-libya-protest-hits-120 [Accessed 12 May 2013].

Speciale, A. (2011) 'Berlusconi’s Libya Conundrum', The Global Post, 22 March.

Saad, L. (2011) 'Americans Resist A Major US Role in Libya', Gallup Politics, 29 March [online]. Available from: http://www.gallup.com/poll/146840/AmericansResist-Major-Role-Libya.aspx [Accessed 06 May 2014].

Schake, K. (2012) 'US Retrenchment Is Right And Overdue', in Tomas Valasek (ed.), All Alone? What US Retrenchment Means For Europe And NATO, Centre for European Reform.

Spangdahlem Air Base (2014) 'US Forces in Poland Strengthen NATO Partnerships During Aviation Rotation', 03 June.

The Guardian (2011) 'Gaddafi Son: "We Will Eradicate Them All”, 21 February [online]. Available from: http://www.theguardian.com/world/2011/feb/21/gaddafi-sonmuammar-libya [Accessed 20 March 2011].

The Guardian (2011) 'Libya on Brink As Protests Hit Tripoli', 21 February [online]. Available from: http:/www.theguardian.com/world/2011/feb/20/libya-defiantprotesters-feared-dead [Accessed 20 March 2011].

The Moscow Times (2011) 'Details Sought on Libya No-Fly Plan', 16 March [online]. Available from: http://www.themoscowtimes.com/sitemap/free/2011/3/article/details-sought-on-libyano-fly-plan/432615.html [Accessed 11 March 2012].

Traynor, I. (2011) 'US Defence Chief Blasts Europe over NATO', The Guardian, 10 
June.

The Telegraph (2011) 'Barack Obama and What He Said on the Iraq War', 14 December [online]. Available from: http://www.telegraph.co.uk/news/worldnews/barackobama/8956959/Barack-Obamaand-what-he-said-on-the-Iraq-war.html [Accessed 09 September 2013].

Tardelli, L. (2011) 'Obama's Interventions: Afghanistan, Iraq, Libya', The United States After Unipolarity, LSE Ideas SR009 December 2011, pp.21-22.

The Economist (2012) 'NATO's Sea of Troubles', 31 March [online]. Available from: http://www.economist.com/node/21551464 [Accessed 15 April 2014].

The Economist (2013) 'The State of the Union: A House Divided', 16 February [online]. Available from: http://www.economist.com/news/united-states/21571877president-delivers-meaty-speech-congress-will-not-find-much-favour [Accessed 20 February 2013].

Traynor, I. (2014) 'Obama Pledges \$1bn to Boost Military in Europe in Wake of Ukraine Crisis', The Guardian, 03 June [online]. Available from: http://www.theguardian.com/world/2014/jun/03/obama-pledge-military-europeukraine-crisis [Accessed 10 June 2014].

The Economist (2014) 'Poland and America: Troops In', 07 June.

UN (2011) A/HRC/S-15/1, 'Report of the Human Rights Council on Its Fifteenth Special Session', 25 February [online]. Available from: http://www2.ohchr.org/english/bodies/hrcouncil/docs/15session/HRC-S-151 AUV.pdf [Accessed 12 April 2012].

UN News Centre (2011) 'Security Council Authorises "All Necessary Measures" to Protect Civilians in Libya', 17 March [online]. Available from: http://www.un.org/apps/news/story.asp?NewsID=37808\#.U6Az9cZyGOA [Accessed 12 November 2013].

US Fed News (2011) Democratic Leader Pelosi Issues Statement Following President Obama's Remarks On Libya, 18 March.

US Fed News (2011) Rep. Boehner Issues Statement On Libya, 20 March.

USA Today (2011) 'Gates: No US Ground Troops in Libya on His Watch', 31 March [online]. Available from: http://usatoday30.usatoday.com/news/washington/2011-0331-gates-mullen-libya_N.htm [Accessed 07 April 2012]. 
US Fed News (2011) DOD: US Continues Support Of NATO Operations In Libya, 20 April.

Wheeler, N. (2002) Saving Strangers: Humanitarian Intervention in International Society, Oxford: Oxford University Press.

Wheeler, N. (2005) 'A Victory for Common Humanity? The Responsibility to Protect after the 2005 World Summit', Conference on 'The UN at Sixty: Celebration or Wake?', 6-7 October 2005, p. 1.

White, G. (2011) 'BP's Contracts in Libya "Still Valid" Despite Turmoil', The Telegraph, 17 March [online]. Available from: http://www.telegraph.co.uk/finance/newsbysector/energy/oilandgas/8389397/BPscontracts-in-Libya-still-valid-despite-turmoil.html [Accessed 18 August 2013].

Weiss, T. (2011) 'RtoP Alive and Well after Libya', Ethics \& International Affairs, Vol. 25, No. 3, p. 290.

Whitlock, G. (2012) 'NATO allies grapple with shrinking defence budgets', Washington Post, 13 January.

White House (2012) 'Sustaining US Global Leadership: Priorities for $21^{\text {st }}$ Century Defence', 03 January [online]. Available from: http://www.defense.gov/news/defense_strategic_guidance.pdf [Accessed 07 February 2012]. 